\title{
The Effects of Pre-service English Language Teachers' Making Vocabulary Learning Materials in Web-Supported Situated Learning Environment on Their Vocabulary Learning
}

\author{
Kerim Ünal $^{1} \&$ Tuğba Yanpar Yelken ${ }^{1}$ \\ ${ }^{1}$ Faculty of Education, Mersin University, Mersin / TURKEY \\ Correspondence: Kerim ÜNAL, Mersin Üniversitesi Eğitim Fakültesi Yabancı Diller Eğitimi Bölümü, B Blok \\ Kat:1 Çiftlikköy Kampüsü - Mezitli / Mersin / Turkey.
}

This article was generated from the Ph.D. Thesis “The Effects of Pre-Service English Language Teacher' Making Vocabulary Learning Materials in Web-Supported Situated Learning Environment on Their Vocabulary Learning."

Received: February 27, 2020

Accepted: March 20, 2020

Online Published: March 21, 2020

doi: 10.5539/elt.v13n4p52

URL: https://doi.org/10.5539/elt.v13n4p52

\begin{abstract}
The aim of this study was not only to help pre-service English language teachers (PS-ELTs) to design vocabulary learning materials for a web-supported situated learning (SL) environment but also to have them learn the vocabulary they used to prepare those materials in the web-supported SL environment. Also, the effects of this process on the PS-ELTs' academic achievement, self-efficacy beliefs in designing situated learning environments (SEB-SLE), and technological pedagogical content knowledge self-confidence (TPACK-SC) were revealed. One of the advanced mixed-method designs, intervention design, was employed, and 56 PS-ELTs participated in the study. The data were collected via quantitative measurements (two scales, a vocabulary achievement test) and qualitative measurements (student diary, online messaging logs, open-ended interview form, and focus group interview records). For the quantitative data, independent samples t-test, related-samples t-test, and $2 \mathrm{X} 3$ repeated measures ANOVA test were used; for the qualitative data, content analysis. The results showed that there was a significant difference between the within-group gain scores and retention test scores in terms of the vocabulary achievement test and the SEB-SLE scale. However, despite a significant difference in the within-group gain scores in terms of the TPACK-SC scale, no significant difference was found between the post-test and retention test scores. Moreover, although both groups revealed no significant differences in the scores of the vocabulary achievement test and the TPACK-SC scale, the scores of the SEB-SLE scale showed a significant difference in favor of the treatment group. Related to the procedure, PS-ELTs highlighted that preparing vocabulary learning materials according to the web-supported SL model had a considerable effect on their vocabulary learning. Besides, the application process supported permanent learning and vocabulary knowledge development. What is more, the procedure helped them gain critical thinking, problem-solving, synthesis, and research skills as well as improving their TPACK.
\end{abstract}

Keywords: situated learning, teacher education, vocabulary learning, self-efficacy, material design

\section{Introduction}

Foreign language education focuses on the development of four core language skills (listening, writing, reading, and speaking). Grammar and vocabulary teaching also play an essential role in the improvement of these skills. However, vocabulary learning and teaching processes have always been among the main problems in foreign language education because foreign language teachers tend to attach importance to morphology and syntax (Richards, 1976; Huffman, 2011), and always ignore vocabulary teaching and learning strategies.

For this reason, many learners find it difficult to learn vocabulary and improve their vocabulary knowledge due to the overload of words given by the teachers and the lack of motivation (Jaeyoung \& Graf, 2008). In vocabulary learning and teaching process, the teacher provides a list of words and their equivalents in the mother tongue, and the learners try to learn the meaning of these words out of context. However, such a vocabulary learning process does not go beyond trying to memorize the native language equivalents of those given in the 
target language (Shrum and Glisan, 2015). When the situation is only memorizing words, learners do not know how to learn vocabulary effectively, as a result of which they only employ memorization strategies (Huang and Eslami, 2013). Besides, how words can be used for meaningful purposes both inside and outside the classroom (Yang, 2011) is usually not shown to the learners.

The nature of learning involves such processes as the interaction of individuals with others and their environment, their participation in social practices, the interaction of individuals within the group, cooperation, and construction of information socially (Xioa-fang and Ting, 2011). Studies show that rather than providing only dictionary meanings or equivalents of vocabulary in the native language or trying to learn them in this way, giving words in a context and supporting with visuals yields more effective results (Brown, Collins, and Duguid, 1989; Chun and Plass, 1996; Shahrokni, 2009). Brown, Collins, and Duguid (1989) emphasized that learning the words as disconnected from their definitions or context is a slow and unsuccessful process; on the contrary, the individuals grasp vocabulary easier in the communication process mostly used in daily life. Therefore, the use of authentic, meaningful, and contextual learning environments has become prominent in teaching vocabulary (Brown et al., 1989; Lave and Wenger, 1991). Various theorists and researchers have emphasized that the use of meaningful contexts has positive effects to help learners master the words in the target language effectively (Gibbons, 2009; Webb, 2008).

Learning a new language takes place either as a second language requiring practical usage of the target language in the society or as a foreign language lacking the usage of the target language by the community. If the community uses the target language, learners have a significant advantage because they have the chance to use the target language in real contexts, and vocabulary learning takes place in the actual setting (Özverir and Herrington, 2011). However, if the society does not use the target language to be studied, problems in the process of learning a foreign language will arise because learners do not have the chance to use the target language in real contexts. To overcome this problem, teachers must provide authentic environments and meaningful contexts for learners. So, Gibbons (2009) proposed four strategies to teach vocabulary effectively: a) present the meanings of the words in context, b) have the learners participate actively in the learning process and spend some time in the process, c) show the learners the usage of the words in different situations, and d) create environments where target words are used.

When the strategies proposed by Gibbons (2009) are taken into consideration, it is stated that teaching the target words in meaningful contexts is more effective in supporting permanent learning (Snow, 2010) than just providing a list of words. Therefore, it falls to foreign language teachers to create social environments in the classroom that will enable learners to use and learn the words given effectively and permanently. However, foreign language teachers who prefer memorization strategy may have difficulty in implementing the Gibbons' (2009) approach. As a result, they may continue to teach vocabulary similarly or push it into the background. Therefore, it is crucial not only to create real social environments where PS-ELTs can have the opportunity to utilize the words they learn during their language learning process but also to train them on how to create social environments for vocabulary teaching. Thus, they can focus on vocabulary teaching rather than push it into the background (Kirshner and Whitson, 1997; Liaw and Susan, 2010; Yang, 2011) when they become teachers.

So, one way to provide this is to employ the situated learning method (SLM), in which individuals share information in a real or near-realistic context, to create a social environment in the classroom. Language development occurs as a result of interaction with other individuals in the social environment. Besides, individuals make sense of and construct information during the activities they perform within the application community in which they live. Thus, situated learning (SL) is the state of creating meaning from real events in daily life where learning takes place (Stein, 1998). Furthermore, when the ongoing interaction between learners and their environment was considered, SL explains the state of cognition, including such mental processes as problem-solving, interpretation, understanding, transfer of information, and creativity (Clancey, 1995). Collins, Hawkins, and Carver (1991) provided two examples where this method was employed: 1) they suggested in their study that reading and writing teaching could be made situated in a context in which students prepare a file using the knowledge they have learned in the field of science. 2$)$ in his experimenting school, Dewey (1969, in Collins et al., 1991) created a situated learning environment in a study by asking students to design and build a clubhouse that would reveal students' planning and arithmetic skills.

Thanks to the developing technology, using computers and their facilities (such as virtual environments and web environments) to create SL environments in the classroom has gained importance (Collins et al., 1991). Furthermore, with the development of computer-assisted language teaching, studies on combining language teaching and computer-assisted communication are also increasing (Kessler and Bikowski, 2010; Liaw and Susan, 2010; Yang, 2011). The computer-assisted communication environment helps to strengthen both the 
communication between the teacher and the student as well as the cooperation between the students by using synchronous and asynchronous communication (Peterson, 2009).

The review of research conducted on SL shed light on the fact that SL has a positive effect on attitude (Gökdaş, 2003; Ünlü, 2009; Chou, 2015), perception (Lee, Kim, Lee and Liu, 2005; Ünal and Inan, 2010), success (Gökdaş, 2003; Ünlü, 2009; Sandberg Maris and de Geus, 2011; Chang and Liu, 2013), self-efficacy (Dönmez, 2005), transfer of information (Gökdaş, 2003), acquisition of information (Zheng, 2010), emotional intelligence (Özerbaş, 2004), collaboration (Huang, Lubin \& Ge, 2011), artistic creativity (Brinck, 2007), problem-solving skills (Ataizi, 1999), learner participation (Yang, 2011; Wicha and Temdee, 2013), and motivation (Ruso, 2007). Besides, there were also some studies conducted on designing multimedia environments according to SL model (Tretiakov, Kinshuk and Tretiakov, 2003; Yang, Tseng, Liao and Liang, 2013), adult education (Stein, 1998; Kim and Marriam, 2010) and on opinions about the usage of the SL model (Şensoy, 2013; Bozu, 2014). In the studies conducted with pre-service teachers, the effect of using SL model in educational technologies course and the effect on the attitudes of teacher candidates' telling stories in the teaching practice were examined, and SL model was found to have a positive effect on the attitudes of pre-service teachers, teachers, and students.

When the research about the use of SL model in language teaching was reviewed, it was seen that SL environments were used in academic language teaching (Mills, 2011), teaching writing skills (Hwang, Chen, Shadiev, Huang and Chen, 2014), vocabulary learning (Bilgin Uz, 2016; Chen and Li, 2010; Huang, Yang, Chiang and Su, 2016) and speaking skills (Efe, Demiröz and Akdemir, 2011; Shih and Young, 2008; Yang, 2011; Xiao-fang and Ting, 2011). Besides, social media, online meeting environments, and virtual classroom applications as SL environments were also used for teaching general language skills. The findings of the research showed that SL environments contribute significantly to the development of language. As a result, the SL model can be used not only to create real social environments where PS-ELTs can have the opportunity to utilize the words they learn during their language learning process but also to train them on how to create social environments for vocabulary teaching because they do not receive much training exclusively on how to teach vocabulary during their pre-service training period.

Therefore, this study aims to have PS-ELTs both prepare web-supported situated vocabulary teaching materials and help them develop their vocabulary learning skills and vocabulary knowledge while they are preparing web-supported situated vocabulary teaching materials in the web-supported situated learning environment. With this application, PS-ELTs are expected to gain experience in how to teach target words effectively and permanently to their students when they begin their teaching life. Thus, the fact that pre-service teachers prepare their web-supported SL products and use these materials in their vocabulary learning processes is a feature not found in other studies. What is more, there are not many studies that demonstrate the application stages of the SL model. In this study, a model for the application stages of this model is proposed. In this respect, this study is thought to contribute to the literature.

In summary, this study aims to have PS-ELTs both prepare web-supported situated vocabulary teaching materials with advanced-level vocabulary and help them develop their vocabulary learning skills and vocabulary knowledge during this application designed in the web-supported situated learning environment. Aside from this, it also aims to find out the effects of this process on their academic achievement, self-efficacy beliefs to create a situated learning environment (SEB-SLE) and technological pedagogical content knowledge self-confidence (TPACK-SC).

\subsection{Problem Sentence and Sub-Problems}

What is the effect of the PS-ELTs' preparation of vocabulary materials according to the web-supported situated learning model in the web-supported situated learning environment on their academic achievement, SEB-SLE, and TPACK-SC?

1. Is there a significant difference between the pre-test, post-test, and retention test scores of PS-ELTs preparing web-supported SL environments (Treatment Group) and those preparing expository teaching environments (Control Group) in their vocabulary learning process in terms of a) academic achievement related to vocabulary learning, b) TPACK-SC and c) SEB-SLE?

2. What is the predictive power of TPACK-SC and SEB-SLE of PS-ELTs on their academic achievement in vocabulary learning?

3. What are the opinions of PS-ELTs about learning vocabulary in a web-supported SL environment?

4. What are the opinions of PS-ELTs about teaching vocabulary in a web-supported SL environment? 
5. What are the opinions of PS-ELTs about the effect of preparing vocabulary learning materials according to the web-supported SL model on their professional development?

\section{Research Method}

\subsection{Research Model}

In line with the aims of this very study, the design of the study was quasi-experimental, and qualitative and quantitative data were collected separately, evaluated, and combined for the results to see both qualitative and quantitative pictures of the quasi-experimental application results. Therefore, the design of this study is an advanced type of basic mixed method, intervention mixed-method design (Cresswell, 2015). The method and process of the study are given in Figure 1, according to the intervention mixed-method design.

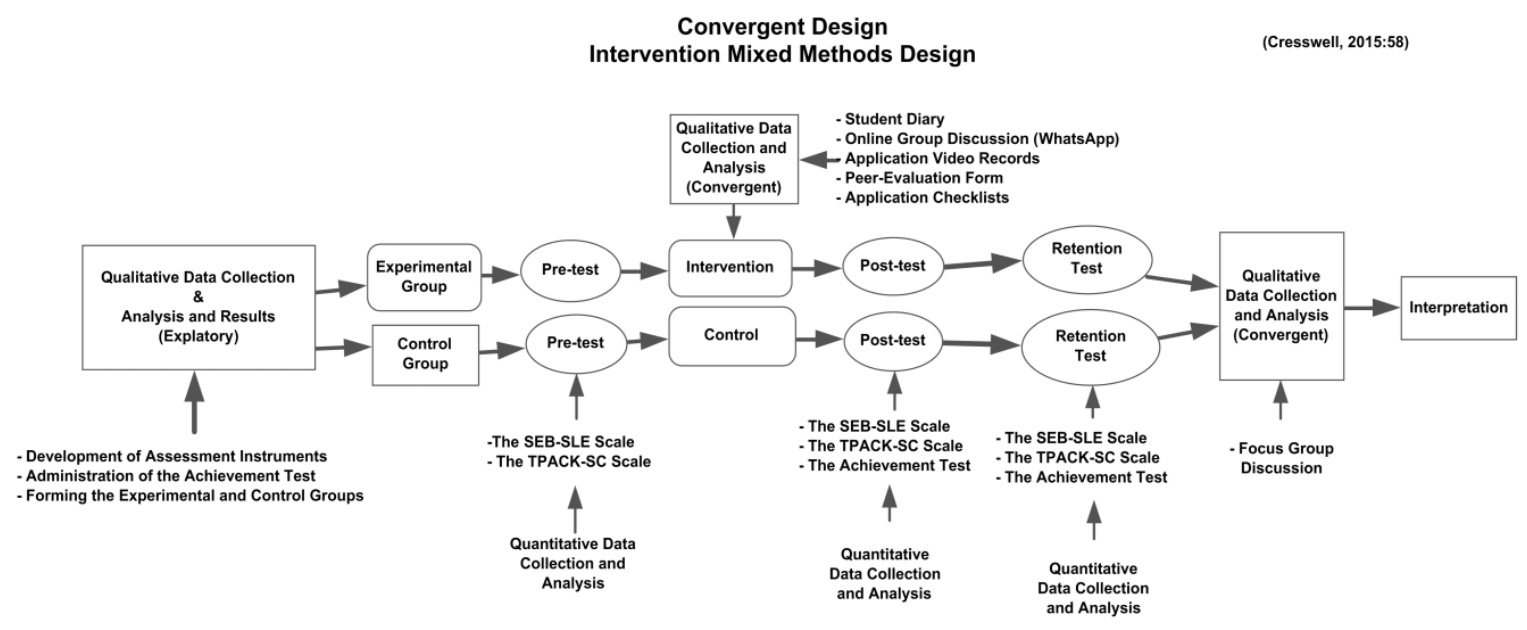

Figure 1. Research Method and Procedure

\subsection{Participants}

Since one of the aims of the study was to have pre-service teachers prepare SL materials, the study group of this research constitutes 4th-grade PS-ELTs, in the faculty of education in a state university in Turkey, who took "Material Analysis and Development in Foreign Language Education" course in 2016 - 2017 academic year. 60 PS-ELTs participated in the study. However, four observations were excluded from the analysis because they gave outliers after the tests of normality for the achievement pre-test. Thus, the observations from 56 PS-ELTs were analyzed. Forty (71.4\%) of the PS-ELTs were female; 16 (28.6\%), male. Each group in the study consisted of 20 female and eight male PS-ELTs.

\subsubsection{Equivalence of Treatment and Control Groups}

Independent samples t-test to determine whether the groups are equivalent to each other according to the results of the advanced vocabulary achievement test and Levene's test for the equality of variances were used. The results of the tests showed that both groups (Group A: $n=28, \bar{x}=35.071$, sd $=4.705$; Group B: $n=28, \bar{x}=$ 35.714 , sd $=6.638)$ are statistically equivalent for the treatment. The result of Levene's test for equality of variances $\left(\mathrm{F}_{(54)}=3.614 ; \mathrm{p}=0.063>0.05\right)$ and the result of the independent samples $\mathrm{t}$-test $\left(\mathrm{t}_{(54)}=-0.418\right.$; $\mathrm{p}=0.678>0.05$ ) highlighted that there was no difference statistically among the means of the PS-ELTs' scores, that is both groups can be said to be equal. The groups were appointed as the treatment and control group via the raffle method. Then, the SEB-SLE scale and TPACK-SC scale were applied as pre-tests. Levene's test for normality of distribution and independent samples t-test for the equivalence of the groups were also conducted for the observations obtained from the scales.

\subsubsection{Procedures in the Treatment Group}

The procedures applied in the treatment group consisted of three stages. In the first stage, the word "situated" and "situated learning" concepts were explained, and the situated learning model with a demonstration of a sample module prepared in this model was introduced to the group. Then, the PS-ELTs in the treatment group examined the components of the situated learning environment together with the teacher, and questions raised by them were answered.

In the second stage, PS-ELTs developed a vocabulary learning module for the advanced words given to them 
according to the situated learning model shown. They were informed about what the situated learning model is and how to prepare a module before preparing vocabulary learning materials according to the situated learning model (Figure 2).

SITUATED LEARNING MODEL

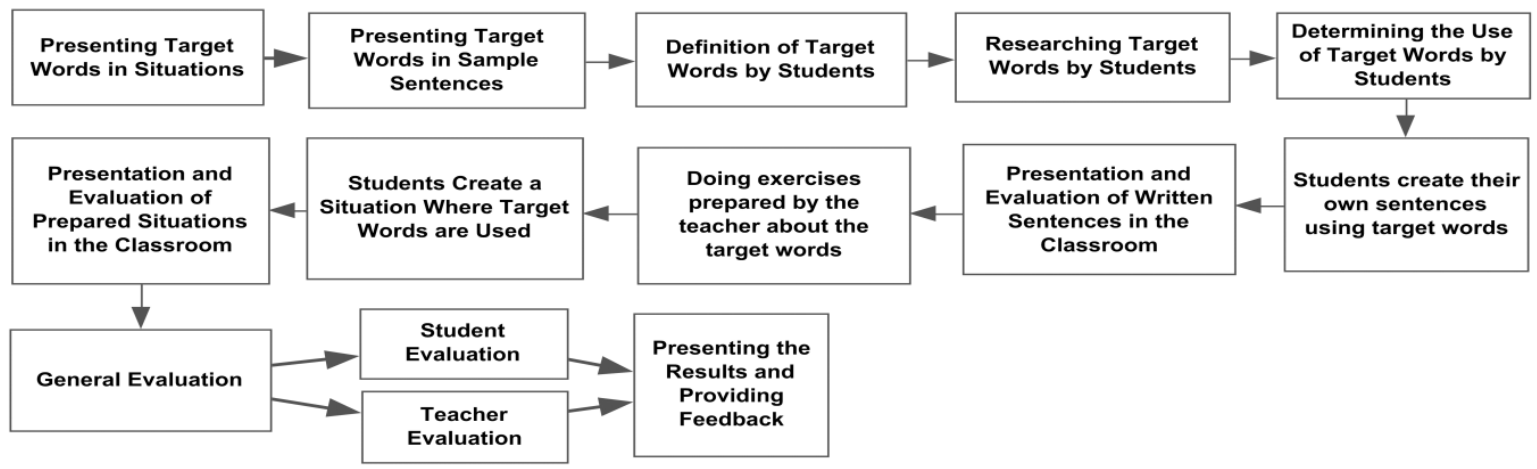

Figure 2. Situated Learning Model

In the third stage, PS-ELTs developed the vocabulary learning module by using the target words in the application process designed according to the situated learning module. The situated learning model experimental study process is given below (Figure 3 ).

Situated Learning Model Experimental Study Process Flowchart

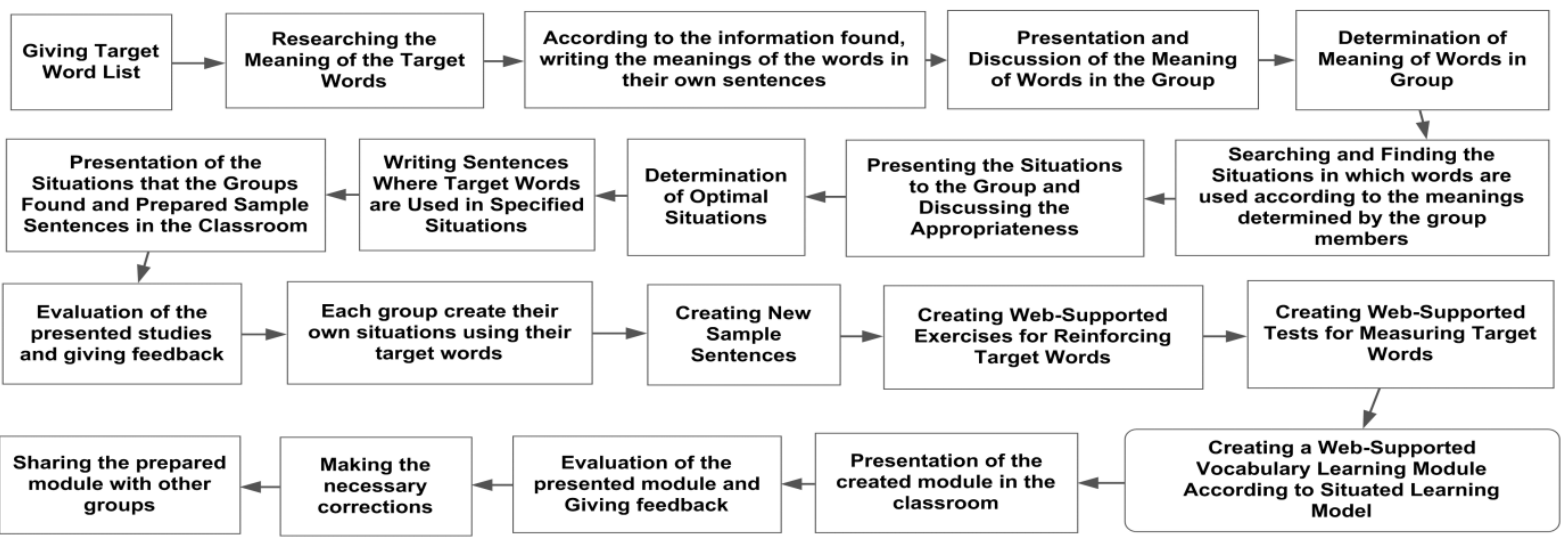

Figure 3. Situated Learning Model Experimental Study Process Flowchart

\subsubsection{Procedure in the Control Group}

PS-ELTs in the control group prepared vocabulary materials according to the expository teaching model in their vocabulary learning process (Figure 4).

PREPARING VOCABULARY LEARNING MATERIAL VIA EXPOSITORY TEACHING MODEL AND VOCABULARY LEARNING

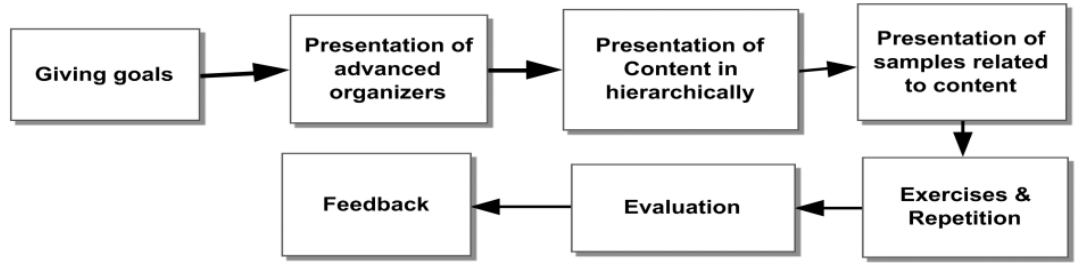

Figure 4. Expository Teaching Model 


\subsection{Data Collection Tools}

Vocabulary achievement test. An 84-item vocabulary achievement test developed by the researcher was used to evaluate the academic achievement of PS-ELTs. During the achievement test development process, "English Vocabulary in Use (Advanced) by Michael McCarthy and Felicity O'Dell - Cambridge University Press" was taken as the sourcebook, and six units out of 100 were randomly selected from the book. It is aimed to teach a total of 84 words in the selected units. A draft version of the vocabulary achievement test was developed to test eighty-four target words in multiple-choice format. In this draft version, three test items for each target word were written. The choices of multiple-choice test items were written by selecting from 84 target words. Two English language education and two assessment and evaluation experts checked the draft version, and required corrections were made in line with the suggestions of the experts. The developed vocabulary achievement test was applied to third and fourth-year students studying in the English Language and Linguistics Department at the Faculty of Arts and Sciences of a state university. Seventy-six students took the vocabulary achievement test. Six students were excluded from the evaluation because they gave blank answer sheets. The analyses were conducted according to the answers of 70 students. "ITEMAN" item analysis program was used to calculate the reliability of the vocabulary achievement test. Each test's reliability was calculated separately. Calculation results are given in Table 1.

Table 1. Reliability Results of the Vocabulary Achievement Test

\begin{tabular}{cccc}
\hline Reliability Results & TEST 1 & TEST 2 & TEST 3 \\
\hline Number of Items & 84 & 84 & 84 \\
Number of Participants & 70 & 70 & 70 \\
Mean & 20.629 & 20.457 & 19.843 \\
Variance & 301.833 & 291.762 & 274.075 \\
Standard Deviation & 17.373 & 17.081 & 16.555 \\
Skewness & 1.344 & 1.207 & 1.362 \\
Kurtosis & 1.598 & 1.437 & 2.018 \\
Minimum & 0.000 & 0.000 & 0.000 \\
Maximum & 73.000 & 75.000 & 73.000 \\
Median & 18.000 & 18.000 & 18.000 \\
KR-20 & 0.961 & 0.959 & 0.957 \\
Standard Error & 3.432 & 3.443 & 3.414 \\
Mean item difficulty & 0.246 & 0.244 & 0.236 \\
Item-Total Mean & 0.486 & 0.476 & 0.471 \\
Bi-serial Mean & 0.672 & 0.657 & 0.659 \\
Mean Discrimination Index & 0.456 & 0.449 & 0.408 \\
\hline
\end{tabular}

It is seen in Table 1 that the mean score of each achievement test is $20.629,20.457$, and 19.843 over 84 points, respectively. The highest score from the 1st and 3rd tests was 73,000, and the highest score from the 2nd test was 75,000 . The KR-20 reliability coefficients of the tests were $0.961,0.959$, and 0.957 , respectively. Remarkably, the results are very close to each other and quite high. These results show that all three tests are quite reliable.

Regarding the mean item difficulty of the tests, Haladyna (1997) stated that the mean item difficulty of a good test should be between 0.20 and 0.60 (p: 239). Accordingly, the average difficulty of the tests is $0.246,0.244$, and 0.236 , respectively. This result is significant in terms of determining the success of PS-ELTs and the effectiveness of the SL method. When the item discrimination index of each item is examined, it is seen that the indexes of the items are above 0.30. In other words, it can be said that the items of all three tests are distinctive. Besides, these results provide evidence of the validity of the tests.

Students' scores from each test were compared to check whether there is an equality between the tests, and given in Table 2. 
Table 2. Correlation Results of the Students' Scores from Each Test

\begin{tabular}{ccccc}
\hline & & TEST1 & TEST2 & TEST3 \\
\hline \multirow{2}{*}{ TEST1 } & Pearson Correlation & 1 & $.947^{* * *}$ & $.946^{* *}$ \\
& Sig. (2-tailed) & & .000 & .000 \\
& $\mathrm{~N}$ & 70 & 70 & 70 \\
TEST2 & Pearson Correlation & $.947^{* *}$ & 1 & $.959^{* *}$ \\
& Sig. (2-tailed) & .000 & & .000 \\
& $\mathrm{~N}$ & 70 & 70 & 70 \\
TEST3 & Pearson Correlation & $.946^{* *}$ & $.959^{* *}$ & 1 \\
& Sig. (2-tailed) & .000 & .000 & \\
& $\mathrm{~N}$ & 70 & 70 & 70 \\
\hline
\end{tabular}

**. Significant at 0.01 level.

There is a significant and strong relationship between tests $(r>0.000 ; p=0.000)$ in the positive direction at the level of 0.01 (Table 2). Besides, there is a significant relationship between test 1 and test $2(r=0.947)$, between test 1 and test $3(r=0.946)$ and between test 2 and test $3(r=0.995)$. So, these tests can be said to be equivalent. In other words, the three tests measure the desired goals and are an indicator that the students can get close scores from all three tests. The final achievement test was created by picking up the items with the highest item difficulty index of the co-items in all three tests. For the 84 items in the final achievement test, the item analysis was repeated, and the KR-20 index was calculated as 0.963 . This result shows that both the test and test items measure the desired objectives. That is, the vocabulary achievement test is a valid and reliable measurement tool.

SEB-SLE Scale. The 51-item SEB-SLE scale developed by the researcher was applied to 331 pre-service teachers. After the factor analysis, a single-factor measurement tool consisting of 49 items was obtained. The reliability coefficient of the measurement tool with a 5-point Likert rating (1-Not at all, 5-very well) was found to be Cronbach's Alpha $=0.966$. The lowest score that can be obtained from the scale is 49 ; the highest score, 245. If the total score of the test is between 49 and 114, it can be interpreted as having a "low" level of SEB-SLE, between 115 and 179, "medium" level and between 180 and 245, "high" level. In this very study, the reliability coefficient of the measurement tool was calculated as Cronbach's Alpha $=0,959$. The mean score is 147. The lowest score obtained from the scale was 119; the highest score, 215.

TPACK-SC scale. Timur and Taşar (2011) carried out the adaptation of the TPACK-SC scale by Graham, Burgoyne, Cantrell, Smith, Clair, and Harris (2009) in Turkish. 5-point Likert type scale ( $1=$ I do not trust at all to 5 = I trust entirely) consists of 31 items and four dimensions: Technological Pedagogical Content Knowledge (TPACK), Technological Pedagogical Knowledge (TPK), Technological Content Knowledge (TCK) and Technological Knowledge (TK). Timur and Taşar (2011) administered the scale to 393 Science and Technology teachers to determine the validity and reliability of the scale. The Cronbach Alpha reliability coefficient of the scale is 0.920 ; the Cronbach Alpha reliability coefficients of its subscales are $0.890,0.870$, 0.890 , and 0.860 , respectively. The lowest score to get from the scale is 26 ; the highest, 155 . In this study, the While Cronbach Alpha reliability coefficient of the scale was 0.890 , the Cronbach Alpha reliability coefficients of its sub-dimensions were $0.905,0.895,0.908$, and 0.858 , respectively.

Student Diary. The student diary designed in Google Forms and filled by the participants online and daily consists of three sections. The first section, where open-ended questions related to the material preparation process according to the SL model were asked, aims to collect data to determine what kind of problems they encounter and what they do to deal with these problems. The second section aims to collect data to reveal the feelings and thoughts of the participants about the application process. In the last section, the participants were asked to evaluate both themselves and other group members in the process of collaborative work. Also, with the help pf the information obtained from the diaries, it is aimed to obtain information that will shed light on the result of the application.

Online Discussion Records (WhatsApp). Groups for the subgroups in the treatment group and the control group were created in the WhatsApp mobile application, which provides instant text messaging, so that the participants in each subgroup can continue the application outside the classroom, discuss and make a decision about the activities as well as consulting the researcher out-off class. The subgroups in the treatment group were named from D-1 to D-7; those in the control group, K-1 to K-7. After the creation of the subgroups, participants 
enrolled in their groups. The researcher was the group admin in each group. Upon the onset of the applications, pre-service teachers started sharing their ideas, opinions, and suggestions in the group.

Application evaluation opinion form. The application evaluation opinion form consisting of twelve open-ended questions was prepared to determine the opinions of the pre-service teachers in the treatment group about the application process at the end of the treatment. One curriculum and instruction expert, one assessment and evaluation expert, and one English language teaching expert checked the prepared form and suggested that five questions be removed from the form because they were the paraphrases of other items in the form. In line with the suggestions of the experts, the final form with seven open-ended questions was created and converted into an online form in Google forms. After the administration of the post-tests, the PS-ELTs in the treatment group filled in the online version of the application evaluation opinion form.

Focus group meeting. After the PS-ELTs filled in the application evaluation interview form, the data obtained from form were analyzed and some questions as to what contributions of the web-supported SL environment has, what the negative aspects of the web-supported SL model are and the reasons why, the reasons why they are for using or against using the model, why group work did not work, how their motivation is affected and why the results of the achievement test were low were created. One from each subgroup in the treatment group, a total of seven participants were randomly selected. A focus group meeting was held with these seven PS-ELTs. The interview was recorded on the video with the permission of the participants.

\subsection{Data Analysis}

For the normality of the distribution of data obtained from the experimental and control groups, the normality test (Shapiro Wilks) was used because the number of samples was 28. The results of the normality test of the distribution, achievement pre-test (treatment group $(\mathrm{TG}) \mathrm{p}=.341$; control group $(\mathrm{CG}) \mathrm{p}=.453$ ); post-test (TG $\mathrm{p}$ $=.055 ; \mathrm{CG} \mathrm{p}=.767) ;$ retention test $(\mathrm{TG} \mathrm{p}=.094 ; \mathrm{CG} \mathrm{p}=.251)$, SEB-SLE scale pre-test (TG $\mathrm{p}=.671 ; \mathrm{CG} \mathrm{p}$ $=.877)$; post-test $(\mathrm{TG} \mathrm{p}=.053 ; \mathrm{CG} \mathrm{p}=.246)$; retention test $(\mathrm{TG} \mathrm{p}=.211 ; \mathrm{CG} \mathrm{p}=.632)$ and TPACK-SC scale pre-test $($ TG $\mathrm{p}=.326 ; \mathrm{CG} \mathrm{p}=.132)$; post-test $(\mathrm{TG} \mathrm{p}=.132 ; \mathrm{CG} \mathrm{p}=.501)$; retention test $(\mathrm{TG} \mathrm{p}=.440 ; \mathrm{CG} \mathrm{p}$ $=.553$ ) showed that significance levels were $\mathrm{p}>0.05$, that is, the distribution was normal. Levene's variance test and independent samples t-test analyses were conducted to examine whether the groups were equivalent to the pre-test scores before the quasi-treatment. According to Levene's variance test results, for all three measuring tools (achievement pre-test $\left(\mathrm{F}\left(_{54}\right)=3.614 ; \mathrm{p}=0.063\right)$; post-test $\left(\mathrm{F}\left(_{54}\right)=0.174 ; \mathrm{p}=0.679\right)$; retention test $\left(\mathrm{F}\left(_{54}\right)\right.$ $=1.769 ; \mathrm{p}=0.189)$, SEB-SLE scale pre-test $\left(\mathrm{F}\left(_{54}\right)=1.127 ; \mathrm{p}=0.293\right)$; post-test $\left(\mathrm{F}\left({ }_{54}\right)=0.288 ; \mathrm{p}=0.594\right)$; retention test $(\mathrm{F}(54)=2.099 ; \mathrm{p}=0.153)$, and TPACK-SC scale pre-test $\left(\mathrm{F}\left({ }_{54}\right)=0.609 ; \mathrm{p}=0.439\right)$; post-test $(\mathrm{F}$ $\left.\left({ }_{54}\right)=0.041 ; \mathrm{p}=0.840\right)$; retention test $\left.\left(\mathrm{F}\left(_{54}\right)=0.705 ; \mathrm{p}=0.405\right)\right)$ levels of significance were found to be $\mathrm{p}>$ 0.05 , that is, the variances of the groups were homogeneous.

In the first sub-problem, $2 \times 3$ repeated measures ANOVA test was used to find out whether there was a significant difference between the groups, and the Bonferroni correction test was used to determine which group favored the difference. The following conditions must be met to use $2 \mathrm{X} 3$ repeated measures ANOVA test (Field, 2009; Can, 2014).

a) The distribution of the data for the dependent variables should be standard within each sub-group (for a total of 18 groups, including experimental and control groups and pre-test, post-test and retention test results of each measurement tool), that is, it should be $p>0,05$ (The normality test results showed that the distribution was normal.),

b) The variances of the groups should be homogeneous, that is, the level of significance of Levene's test results should be $p>0,05$ (Levene's variance test results showed that the variances of the groups are homogeneous),

c) For binary combinations of measurement groups, there should be no significant difference between the groups' covariances (Box Test), that is, it should be $\mathrm{p}>0.001$ (Box test results for the vocabulary achievement test (Box's $\mathrm{M}=46.202, \mathrm{~F}=7.235$ and $\mathrm{p}=0.000$ ); for SEB-SLE scale (Box's $\mathrm{M}=20.619, \mathrm{~F}=3.229$ and $\mathrm{p}=0.004$ ); for the TPACK-SC scale (Box's $M=10.969, F=1.718$ and $p=0.112$ ) were calculated. Only for the TPACK-SC scale, no significant difference between the covariances of the groups was observed.

d) Since the Box test is susceptible, if the p-value is close to 0.001 , instead of multiple variance analysis, Pillai's Trace results should be considered, that is, the significance level of Pillai's Trace results should be $p<0.05$ (Multivariate test Pillai's Trace results, both showed that the significance level of the variable was smaller than $\mathrm{p}$ $=0.000<0.05$.), and

e) The significance level of Mauchly's sphericity test result should be $p>0.05$ (For Mauchly's Sphericity test results (For vocabulary achievement test (Mauchly's $\mathrm{W}=0.910$ and $\mathrm{p}=0.082$ ); for the SEB-SLE scale 
(Mauchly's $\mathrm{W}=0.918$ and $\mathrm{p}=0.104$ ) The significance level was found to be $\mathrm{p}>0.05$ for the TPACK-SC scale (Mauchly's $\mathrm{W}=0.997$ and $\mathrm{p}=0.916$ ). All the results mentioned above revealed that all prerequisites of the $2 \times 3$ repeated measures ANOVA test were met.

In the second sub-problem, linear regression analysis was carried out to determine the self-efficacy beliefs and technological pedagogical content knowledge self-confidence of the PS-ELTs towards creating SL environments, and their predictive power on vocabulary learning. In the third, fourth, and fifth sub-problems, the qualitative data obtained from the diaries, online discussion records, opinion forms, and focus group-meeting were evaluated via content analysis method to reveal the opinions of PS-ELTs about vocabulary learning in a web-supported environment. Different experts performed the content analysis for each group of the data, and Miles\&Huberman's (1994) analysis formula for the content analysis for each group of the data was performed. As a result of content analysis reliability calculations, the reliability of one subtitle was calculated as $83 \%$, while the reliability of other subtitles was between $90 \%$ and $97 \%$.

During the application period, PS-ELTs wrote an online diary about their work and made group discussions outside class using the WhatsApp online communication tool. The data from these tools were recorded electronically. After the application, PS-ELTs filled in the interview form with open-ended questions, and a focus group interview was held with seven PS-ELTs. The content analysis results of the qualitative data collected during and after the process of material preparation and vocabulary learning/teaching according to the web-supported SL model were gathered under the titles of the application process, vocabulary learning process, vocabulary teaching process, and professional development. SPSS v21 was used in the analysis of quantitative data, and NVIVO package programs were used in the analysis of qualitative data.

\section{Findings}

\subsection{Findings Related to the First Sub-Problem}

With the first sub-problem, it was aimed to find out whether there was a significant difference between the pre-test, post-test and retention test scores of the treatment group and control group in their vocabulary learning process in terms of a) academic achievements related to vocabulary learning, b) SEB-SLE and c) TPACK-SC.

Academic achievement: When the PS-ELTs' pre-test, post-test, and retention test mean scores taken from the vocabulary achievement test were examined, the mean score of those $(\mathrm{n}=28)$ preparing the vocabulary learning materials in the SL environment according to the SL model increased from $\bar{x}_{(\mathrm{pre})}=35.07(\mathrm{sd}=4.70)$ to $\overline{\mathrm{x}}_{(\mathrm{post})}=$ $47.86(\mathrm{sd}=9.38)$, yet decreased to $\overline{\mathrm{x}}_{(\text {retention })}=46.04(\mathrm{sd}=8.61)$ eight weeks after the treatment. The same mean scores of those $(\mathrm{n}=28)$ who prepared vocabulary materials according to the expository teaching model were $\overline{\mathrm{x}}$ $(\mathrm{pre})=35.71(\mathrm{sd}=6.63), \overline{\mathrm{x}}_{\text {(post) }}=43.21(\mathrm{ss}=10.23)$ and $\overline{\mathrm{x}}_{(\text {retention) }}=38.71, \mathrm{sd}=7.61$, respectively. Accordingly, it can be said that there was an increase in the vocabulary achievement test results of both groups, while there was a decrease in the retention test results.

Table 3. ANOVA test results of vocabulary achievement test pre-test, posttest and retention test scores

\begin{tabular}{ccccccc}
\hline Source of Variation & $\begin{array}{c}\text { Type III } \\
\text { Sum of Squares }\end{array}$ & df & MS & F & p & Partial $\eta^{2}$ \\
\hline Between Groups & 7319.333 & 112 & & & & \\
Achievement (Pre- Post- Retention Test) & 3845.869 & 2 & 1922.935 & 69.166 & .000 & .562 \\
Group*Achievement & 470.869 & 2 & 235.435 & 8.468 & .000 & .136 \\
Error & 3002.595 & 108 & 27.802 & & & \\
Within Groups & 7880.946 & 55 & & & & \\
Group (Experimental - Control) & 323.149 & 1 & 323.149 & 2.309 & .134 & .041 \\
Error & 7557.798 & 54 & 139.959 & & & \\
Total & 15200.280 & 167 & & & & \\
\hline
\end{tabular}

When the ANOVA test results (Table 3) are examined, it can be said that the academic achievement levels of PS-ELTs in both groups differed from pre-test to retention test $\left(\mathrm{F}_{(2,108)}=69.166, \mathrm{p}<0.05\right)$ and both methods have a significant effect size $\left(\eta^{2}=0.562>0.14\right)$. It can be concluded that in the scores obtained from the three measurements of the vocabulary achievement test, $56 \%$ of the variance can be explained by the application conditions, and the remaining $34 \%$ can be explained by other variables such as classroom and out-of-school experiences, intra-group interaction and individual differences. Within-groups results show that there is a 
significant difference between the means of the pre-test, post-test, and retention test scores of the treatment group and the means of those of the control group $\left(\mathrm{F}_{(1,54)}=2.309, \mathrm{p}=0.134>0.05\right)$. However, when the pairwise comparisons table (Table 4) and the profile plots chart (Figure 5) are examined, it is seen that there is a difference between the measurements.

Table 4. Pairwise comparisons of the vocabulary achievement test pre-test, post-test and retention test mean scores

\begin{tabular}{ccccccc}
\hline \multicolumn{2}{c}{$\begin{array}{c}\text { (I) Vocabulary } \\
\text { Achievement }\end{array}$} & $\overline{\mathrm{x}}$ difference (I-J) & $\mathrm{Se}$ & $\mathrm{P}$ & \multicolumn{2}{c}{$95 \%$ Confidence Interval } \\
\hline \multirow{2}{*}{1} & 2 & $-11.643^{*}$ & 1.257 & .000 & -14.748 & -8.538 \\
& 3 & $-6.982^{*}$ & 1.031 & .000 & -9.531 & -4.434 \\
2 & 1 & $11.643^{*}$ & 1.257 & .000 & 8.538 & 14.748 \\
& 3 & $4.661^{*}$ & .579 & .000 & 3.229 & 6.092 \\
3 & 1 & $6.982^{*}$ & 1.031 & .000 & 4.434 & 9.531 \\
& 2 & $-4.661^{*}$ & .579 & .000 & -6.092 & -3.229 \\
\hline
\end{tabular}

According to the results given in Table 4, it can be said that the post-test scores are higher than the pre-test and retention test scores, and the differences between the mean scores are significant $(\mathrm{p}<0.05)$. The pre-test post-test score difference and the post-test - retention-test score difference are 11.64 and 4.66, respectively, in favor of the post-test.

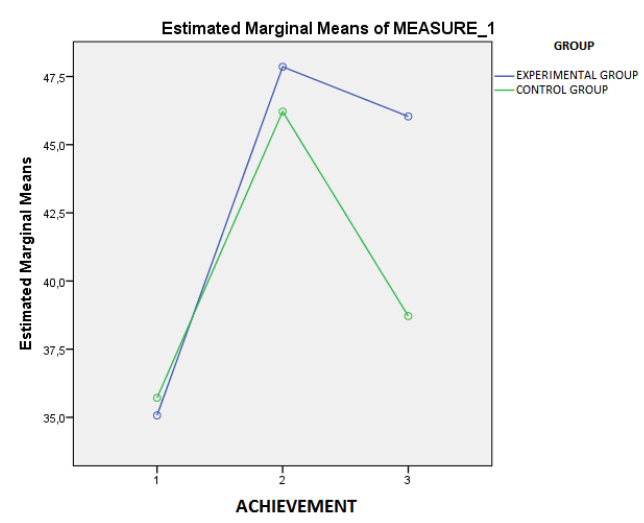

Figure 5. Estimated marginal means of experimental and control groups' achievement test scores

As seen in Figure 5., the mean scores in the pre-test and post-test of both groups can be said to be close to each other. However, there is a difference of 7.4 points in the retention test mean scores $\left(\overline{\mathrm{x}}_{\text {(Experiment) }}=46.036\right.$; $\overline{\mathrm{x}}_{\text {(Control) }}$ $=38.714$ ), and this difference is in favor of the treatment group. In other words, it can be stated that the method used in the treatment group is more effective than that in the control group, and the target vocabulary is remembered more by the PS-ELTs in the treatment group after an eight-week break, which means that the method used in the treatment group provides permanent learning.

SEB-SLE: When the PS-ELTs' pre-test, post-test, and retention test mean scores taken from the SEB-SLE scale were examined, the mean score of those $(n=28)$ preparing the vocabulary learning materials in the SL environment according to the SL model increased from $\overline{\mathrm{x}}($ pre $)=201.07(\mathrm{ss}=19,47)$ to $\overline{\mathrm{x}}($ post $)=251,00$ (ss $=$ $17,95)$, and eight weeks after the treatment to $\bar{x}($ retention $)=229,50(\mathrm{ss}=9.68)$. The same mean scores of those $(\mathrm{n}=$ 28 ) who prepared vocabulary materials according to the expository teaching model were $\overline{\mathrm{x}}($ pre $)=196,71$ ( $\mathrm{ss}=$ $22,54), \overline{\mathrm{x}}($ post $)=210,50(\mathrm{ss}=21,43)$ and $\overline{\mathrm{x}}($ retention $)=196,61, \mathrm{ss}=8,50$, respectively. Although the mean scores of the SEB-SLE scale of the control group increased approximately 19 points after the treatment, the mean scores of the retention test taken eight weeks after the procedure dropped to the mean score they received from the pre-test. 
Table 5. ANOVA test results of SEB-SLE scale pre-test, post-test and retention test scores

\begin{tabular}{ccccccc}
\hline Source of Variation & $\begin{array}{c}\text { Type III } \\
\text { Sum of Squares }\end{array}$ & df & MS & F & p & Partial $\eta^{2}$ \\
\hline Between Groups & 36470.667 & 112 & & & & \\
SEB-SLE Scale (Pre- Post- Retention Test) & 7329.250 & 2 & 3664.625 & 18.341 & .000 & .254 \\
Group* SEB-SLE Scale & 7562.155 & 2 & 3781.077 & 18.924 & .000 & .259 \\
Error & 21579.262 & 108 & 199.808 & & & \\
Within Groups & 36109.280 & 55 & & & & \\
Group (Experimental - Control) & 8134.292 & 1 & 8134.292 & 15.702 & .000 & .225 \\
Error & 27974.988 & 54 & 518.055 & & & \\
Total & 72509.947 & 167 & & & & \\
\hline
\end{tabular}

ANOVA test results (Table 5) indicate that the PS-ELTs who prepared vocabulary learning materials according to two different methods differed before and after the treatment $\left(\mathrm{F}_{(2,108)}=18.341, \mathrm{p}<0.05\right)$. In other words, the PS-ELTs in both groups have different scores from the three measurements for self-efficacy beliefs in creating SL environments and have a large effect size $\left(\eta^{2}=0.254>0.14\right)$. It can be concluded that $25.4 \%$ of the variance can be explained with the application conditions in the scores obtained from three measurements, and the remaining $74.6 \%$ can be explained with other variables such as classroom and out-of-school experiences, intra-group interaction and individual differences. In addition, the means of the pre-test, post-test, and retention test scores of the treatment group and those of the control group $\left(\mathrm{F}_{(1,54)}=8134,292, \mathrm{p}=0.000<0.05\right)$ are significantly different. Also, this difference can be said to be in favor of the treatment group (Figure 6).

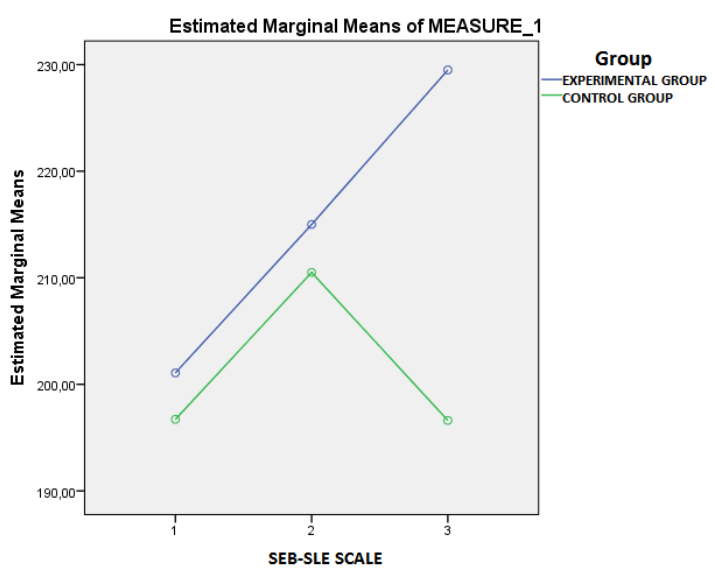

Figure 6. Estimated marginal means of experimental and control group SEB-SLE scale scores

The mean scores of the pre-test and post-test of the SEB-SLE scale in both groups are close to each other (Figure $6)$. However, when the retention test means scores $\left(\overline{\mathrm{x}}_{\text {(Experiment) }}=229.500 ; \overline{\mathrm{x}}_{(\text {Control) }}=196.607\right)$ are compared, the SEB-SLE scale scores of the control group dropped back to the level of that they got in the pre-test while the SEB-SLE scale scores of the treatment group showed a linear increase. That is, the self-efficacy beliefs of the treatment group in creating SL environments have increased even after the experimental process.

TPACK-SC: When the PS-ELTs' pre-test, post-test, and retention test mean scores taken from the TPACK-SC scale were examined, the mean score of treatment group increased from $\overline{\mathrm{x}}_{\text {(pre) }}=120,61(\mathrm{sd}=14,97)$ to $\overline{\mathrm{x}}_{\text {(post) }}=$ $130,40(\mathrm{sd}=13,24)$, but slightly reduced to $\overline{\mathrm{x}}_{(\text {retention })}=129,93(\mathrm{sd}=12,61)$ eight weeks after the treatment. The same mean scores of the control group were $\bar{x}_{(\text {pre })}=116,75(\mathrm{sd}=15,78), \overline{\mathrm{x}}_{\text {(post) }}=124,46(\mathrm{sd}=13,26)$ and $\overline{\mathrm{x}}$ (retention) $=124,32,(\mathrm{sd}=9,94)$, respectively. In general, it is possible to state that the scores obtained by both groups from the TPACK-SC scale increased at the same rate during the treatment but remained constant with the post-test mean scores with a little decrease eight weeks after the application. 
Table 6. ANOVA test results of TPACK-SC scale pre-test, post-test and retention test scores

\begin{tabular}{ccccccc}
\hline Source of Variation & $\begin{array}{c}\text { Type III } \\
\text { Sum of Squares }\end{array}$ & df & MS & F & p & Partial $\eta^{2}$ \\
\hline Between Groups & 13540.000 & 112 & & & & \\
TPACK-SC Scale (Pre- Post- Retention Test) & 2762.607 & 2 & 1381.304 & 13.895 .000 & .205 \\
Group* TPACK-SC Scale & 34.798 & 2 & 17.399 & .175 & .840 & .003 \\
Error & 10736.595 & 108 & 99.413 & & & \\
Within Groups & 36109.280 & 55 & & & & \\
Group (Experimental - Control) & 1105.720 & 1 & 1105.720 & 3.228 & .078 & .056 \\
Error & 18496.940 & 54 & 342.536 & & & \\
Total & 19602.66 & 67 & & & & \\
\hline
\end{tabular}

In line with the ANOVA results given in Table 6, it can be said that the TPACK-SC levels of both the treatment and the control groups differed significantly after the treatment $\left(\mathrm{F}_{(1,54)}=13.895, \mathrm{p}<0.05\right)$. That is, it can be stated that the pre-service teachers in both groups have different scores from the three measurements for the TPACK-SC scale and have a large effect size $(\mathrm{n} 2=0.205>0.14)$. It can be concluded that $20.5 \%$ of the variance can be explained with the application conditions in the scores obtained from three measurements, and the remaining $79.5 \%$ can be explained with other variables such as classroom and out-of-school experiences, intra-group interaction and individual differences. Moreover, there is a significant difference between the means of the pre-test and post-test scores of the treatment group and those of the control group while the means of the retention test scores $\left(\mathrm{F}_{(1,54)}=3,228, \mathrm{p}=0.078>0.05\right)$ of both groups show no significant difference.

The pairwise comparisons table (Table 7) and the estimated marginal means of treatment and control group TPACK-SC scale scores (Figure 7) show a significant difference between the scores of the pre-test and those of the post-test and retention test in favor of post-test and retention test in both groups. Nevertheless, there is no significant difference between the scores of the post-test and retention test.

Table 7. Pairwise comparisons of the TPACK-SC scale pre-test, post-test and retention test mean scores

\begin{tabular}{|c|c|c|c|c|c|c|}
\hline \multirow{2}{*}{\multicolumn{2}{|c|}{ (I) $\mathrm{TPACK}-\mathrm{SC}$}} & \multirow{2}{*}{$\overline{\mathrm{x}}$ difference $(\mathrm{I}-\mathrm{J})$} & \multirow{2}{*}{$\mathrm{Se}$} & \multirow{2}{*}{$P$} & \multicolumn{2}{|c|}{ 95\% Confidence Interval } \\
\hline & & & & & Lower Bound & Upper Bound \\
\hline \multirow{2}{*}{1} & 2 & $-8.750^{*}$ & 1.881 & .000 & -13.398 & -4.102 \\
\hline & 3 & $-8.446^{*}$ & 1.932 & .000 & -13.220 & -3.672 \\
\hline \multirow{2}{*}{2} & 1 & $8.750^{*}$ & 1.881 & .000 & 4.102 & 13.398 \\
\hline & 3 & .304 & 1.838 & 1.000 & -4.239 & 4.846 \\
\hline \multirow{2}{*}{3} & 1 & $8.446^{*}$ & 1.932 & .000 & 3.672 & 13.220 \\
\hline & 2 & -.304 & .1 .838 & 1.000 & -4.846 & 4.239 \\
\hline
\end{tabular}

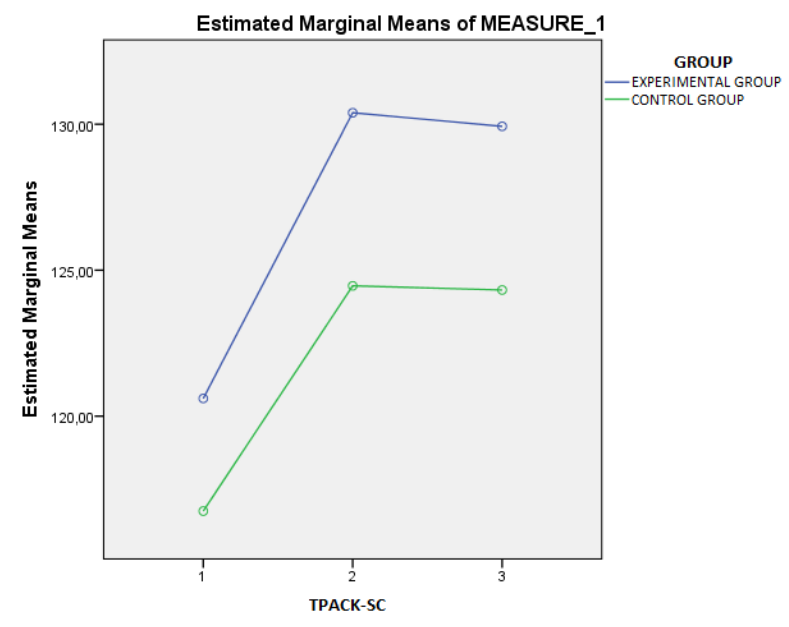

Figure 7. Estimated marginal means of experimental and control group TPACK-SC scale scores 
The graph of the means scores of the TPACK-SC scale of both groups (Figure 7) shows that the TPACK-SC of the PS-ELTs increased in the application process. However, according to the retention test scores, it can be said that the PS-ELTs in both groups did not have an increase or decrease in their TPACK-SC and kept their confidence levels virtually the same.

\subsection{Findings Related to the Second Sub-problem}

The predictive power of TPACK-SC and SEB-SLE of PS-ELTs on their academic achievement in vocabulary learning was investigated (Table 8), and it was observed that SEB-SLE and TPACK-SC variables were in a significant relationship with the academic achievement of the PS-ELTs $(\mathrm{R}=0.406 . \mathrm{R} 2=0.165 . \mathrm{P}=0.008$ $<0.05)$.

Table 8. Academic achievement regression analysis results

\begin{tabular}{cccccccc}
\hline Variable & $\mathrm{B}$ & $\mathrm{SH}$ & $\beta$ & $\mathrm{t}$ & $\mathrm{p}$ & Zero-order $\mathrm{r}$ & Partial $\mathrm{r}$ \\
\hline (Constant) & 0.290 & 14.687 & & 0.020 & .984 & & \\
SEB-SLE & 0.184 & 0.065 & 0.392 & 2.826 & .007 & .405 & .355 \\
TPACK-SC & 0.023 & 0.106 & 0.030 & 0.216 & .830 & .197 & .027 \\
& $\mathrm{R}=0.406$ & $\mathrm{R}^{2}=0.165$ & $\mathrm{~F}_{(2.53)=} 5.225$ & $\mathrm{p}=0.008$ & & & \\
& ACADEMIC ACHIEVEMENT $=0.290+(0.184 *$ SEB-SLE $+0.023 *$ TPACK-SC $)$ & \\
\hline
\end{tabular}

However, from these two variables, only SEB-SLE is a significant predictor $(\mathrm{B}=0.184 ; \mathrm{p}=0.007<0.05)$, while the other variable is not significant, that is, it has no effect. SEB-SLE predicts $16.5 \%$ of academic achievement. According to the regression analysis result, the regression equation predicting academic success is as follows (Equation 1):

$$
\text { ACADEMIC ACHIEVEMENT }=0.290+(0.184 * \text { SEB-SLE }+0.023 * T P A C K-S C)
$$

This equation shows that while an increase of 0.184 in SEB-SLE level causes a one-unit increase in academic achievement level, TPACK-SC has a minor effect on the level of achievement.

The predictive power of academic achievement and TPACK-SC of PS-ELTs on their SEB-SLE was investigated (Table 9), it was observed that academic achievement and TPACK-SC variables were in a significant relationship with the SEB-SLE of the PS-ELTs $\left(\mathrm{R}=0.537, \mathrm{R}^{2}=0.289, \mathrm{p}=0.000<0.05\right)$. With academic achievement and TPACK-SC variables, SEB-SLE explains $29 \%$ of the total variance together $(\mathrm{R} 2=0.289)$.

Table 9. SEB-SLE regression analysis results

\begin{tabular}{cccccccc}
\hline Variable & $\mathrm{B}$ & $\mathrm{SH}$ & $\beta$ & $\mathrm{t}$ & $\mathrm{p}$ & Zero-order $\mathrm{r}$ & Partial $\mathrm{r}$ \\
\hline (Constant) & 108.261 & 24.779 & & 4.369 & 0.000 & & \\
Achievement & 0.587 & 0.192 & 0.360 & 3.051 & 0.004 & .426 & .387 \\
TPACK-SC & 0.712 & 0.252 & 0.334 & 2.826 & 0.007 & .405 & .362 \\
& $\mathrm{R}=0.537$ & $\mathrm{R} 2=0.289$ & $\mathrm{~F}_{(2.53)}=10.764$ & $\mathrm{p}=0.000$ & & &
\end{tabular}

SEB-SLE $=108.261+0.587 *$ Achievement $+0.712 *$ TPACK-SC

The coefficients of the vocabulary achievement and TPACK-SC variables $(B=0.587, p=0.004 ; B=0.712, p=$ 0.007 ) show that they are significant predictors of SEB-SLE. According to the results of the regression analysis, the regression equation (mathematical model) for predicting SEB-SLE is given below (Equation 2).

$$
\text { SEB-SLE }=108.261+0.587 * \text { Achievement }+0.712 * T P A C K-S C
$$

It can be stated that an increase of 0.71 in the TPACK-SC level and 0.58 in academic achievement scores caused a one-unit increase in the level of SEB-SLE. Based on this result, PS-ELTs need to master both TPACK and content knowledge to create web-supported SL environments.

\subsection{Findings Related to the Third Sub-problem}

PS-ELTs answered open-ended questions about whether the treatment has any effect on their vocabulary learning, and the content analysis results of the responses are given in Figure 8. 


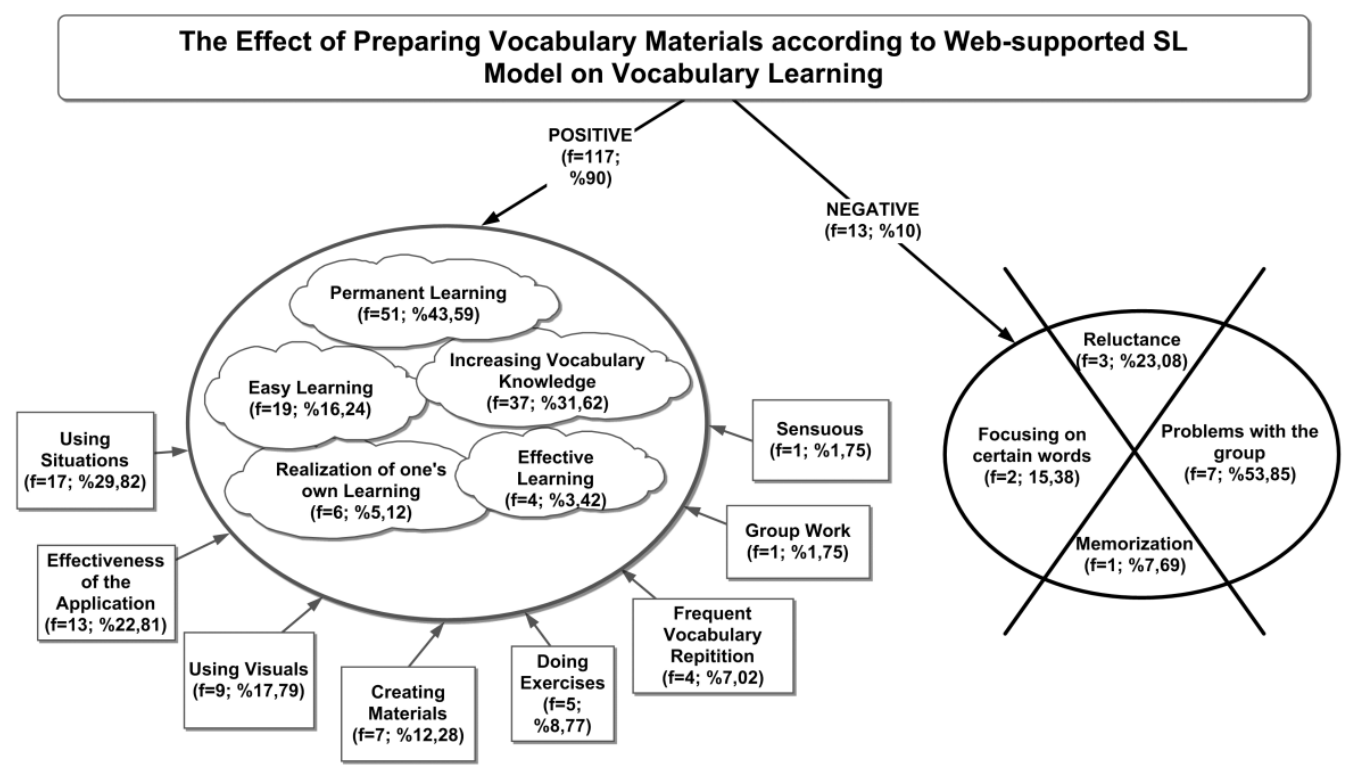

Figure 8 . The effect of the preparation of vocabulary material according to the web-supported SL model on vocabulary learning $(\mathrm{n}=28)$

PS-ELTs emphasized (Figure 8) that their preparation of vocabulary materials according to the web-supported SL model has a great effect ( $f=117 ; 90.00 \%)$ on their vocabulary learning. They also stated that their preparation of vocabulary materials according to the web-supported SL model provided permanent ( $\mathrm{f}=51$; $43.59 \%)$, easy ( $\mathrm{f}=19 ; 16.24 \%)$ and effective $(\mathrm{f}=4 ; 3.42 \%)$ learning, and increased their vocabulary knowledge at the end of the application $(f=37 ; 31.62 \%)$ and awareness of their learning $(f=6 ; 17.79 \%)$. Moreover, they underlined the fact that all phases of the web-supported SL model $(\mathrm{f}=13 ; 22.81 \%)$ were effective, yet the use of the situations in which the target words are utilized $(\mathrm{f}=17 ; 29.82 \%)$ has a high impact on their vocabulary learning process. The use of images ( $f=9 ; 17.79 \%$ ), the creation of materials $(f=7 ; 12.28 \%)$, the search for situations or images where target words are used before creating materials and activities $(f=5 ; 8.77 \%$ ), continuous repetition of the target words $(\mathrm{f}=4 ; 7.02 \%)$ during the creation of the materials, collaboration with the group members $(\mathrm{f}=1 ; 1.75 \%)$ and that the prepared materials address the senses $(\mathrm{f}=1(1.75 \%)$ respectively also affected PS-ELTs' vocabulary learning processes.

Some exemplary statements of the PS-ELTs who shared positive opinions about the effect of web-supported SL model on vocabulary learning processes are as follows:

"While preparing the materials, finding the meanings of the words first, then supporting them with pictures, videos, and creating our situations suitable for the words made the learning of the word easier and more permanent." (P.T.6). "Instead of writing the words five times and memorizing them or just finding the meanings from the dictionary, creating situations and using them in a context at the same time helped us understand the places and meanings of words in the sentence better." (P.T.25).

Although PS-ELTs shed light on the fact that the web-supported SL model had a $90 \%$ positive effect on the vocabulary learning process, some PS-ELTs underlined that this model did not affect their vocabulary learning process $(\mathrm{f}=13 ; 10.00 \%)$. The PS-ELTs who have negative opinions stated the reasons for the ineffectiveness of this model as follows (Figure 8): participant problems in the group work ( $\mathrm{f}=7 ; 53.85 \%$ ), unwillingness to participate in the study ( $\mathrm{f}=3 ; 23.08 \%$ ), sharing the target words to be used for the materials within the group members instead of dealing with all the words $(\mathrm{f}=2 ; 15.38 \%)$. One pre-service English language teacher interestingly stated that the model was ineffective in that the model does not support the memorization of words $(\mathrm{f}=1 ; 7.69 \%)$.

Some exemplary statements of the PS-ELTs who shared negative opinions about the effect of web-supported SL model on vocabulary learning processes are as follows:

"I will not say it has many effects. The event is good, but we had some problems during the application phase. Agreement with the group, gathering, consultation, etc. I think it would be more effective if we focused hard." (P.T.9). "I think it does not help me much to learn words. Because I was in the same group of people I did not 
want. I was constantly striving to have my group mates do something, and it was challenging for us to do something together. First of all, in this kind of group assignments, I find it more useful for the teacher not to make students a group randomly, rather have students group with their friends. If it were like that. It would be more active and useful in vocabulary learning. Because the most important thing is volunteering, I think. It was the lack of volunteering in general that made us lose the most." (P.T.5).

\subsection{Findings Related to the Fourth Sub-problem}

The opinions of the PS-ELTs about whether they will employ the web-supported SL model to teach vocabulary in their teaching career and the reasons why are shown in Figure 6. While the vast majority of PS-ELTs $(n=21$; $75.00 \%$ ) expressed that they could use the web-supported SL model in their vocabulary teaching processes, six PS-ELTs $(21.43 \%)$ stated that they could use the model in their vocabulary teaching processes depending on the circumstances. However, one pre-service English language teacher (3.57\%) emphasized that they would not use the model at all. When the reasons why the PS-ELTs who stated that they would use the web-supported SL model in their vocabulary teaching processes were examined, they were grouped under two headings: teaching process $(\mathrm{f}=40 ; 72.72 \%)$ and learning process $(\mathrm{f}=15 ; 27.28 \%)$.

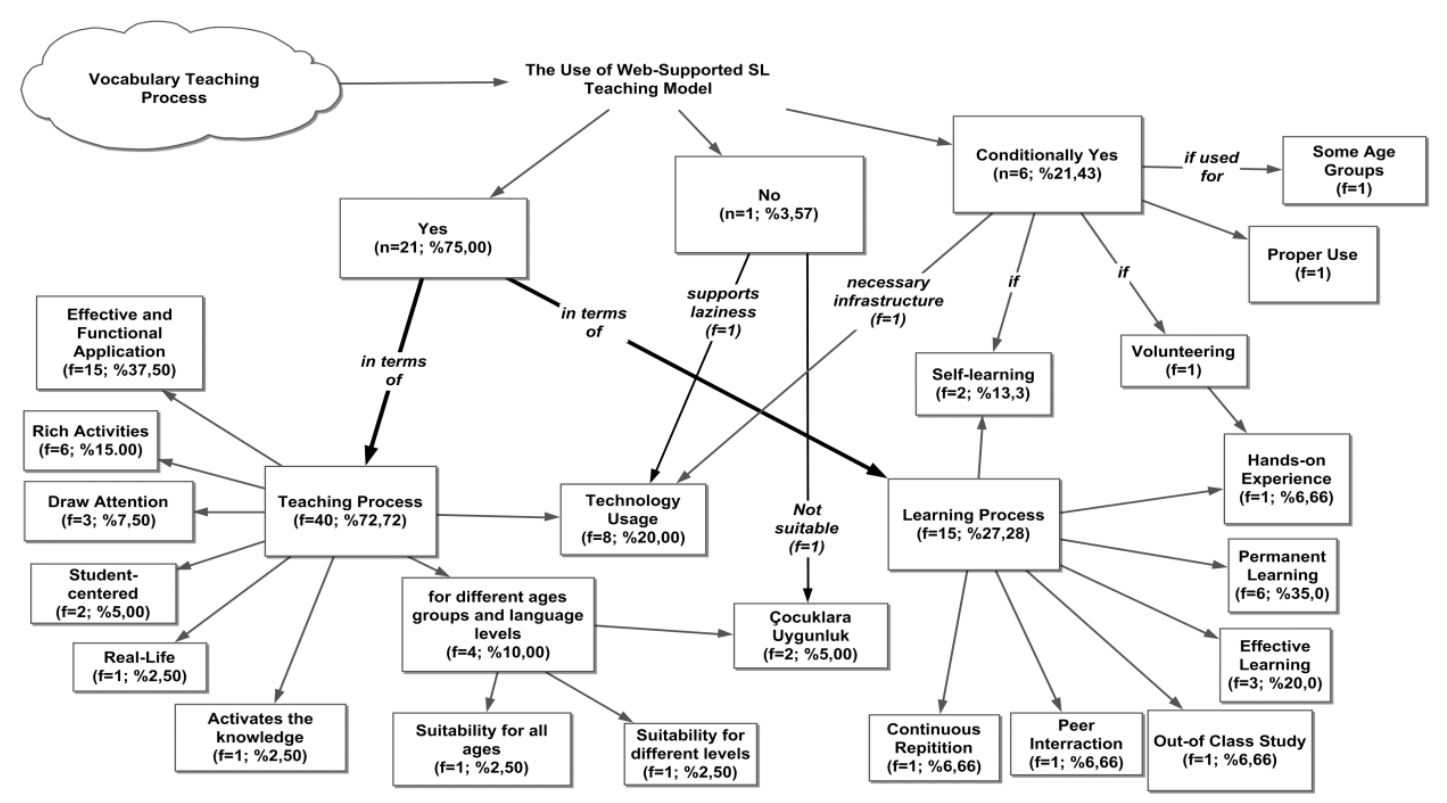

Figure 9. Opinions of the pre-service teachers on the use of web-supported SL model in the vocabulary teaching process $(\mathrm{n}=28)$

In regards to the teaching process (Figure 9), PS-ELTs pinpointed that they will use the model with all the stages primarily because it has an effective and functional application process ( $\mathrm{f}=15 ; 37.50 \%)$. Additionally, the other reasons they asserted to use the web-supported SL model are the use of technology ( $f=8 ; 20.00 \%$ ), richness in activity ( $f=6 ; 15.00 \%$ ), and the suitability for different age groups and language levels $(f=4 ; 10.00 \%)$, effective in attracting the student's attention $(\mathrm{f}=3 ; 7.50 \%)$, student-oriented activities $(\mathrm{f}=2 ; 5.00 \%)$, real-life activities ( $\mathrm{f}=1 ; 2.50 \%)$ and help the student visualize the information in his mind ( $\mathrm{f}=1 ; 2.50 \%)$, respectively.

From the perspective of the learning process, PS-ELTs pinpointed that they would use the web-supported SL model because it provides permanent $(f=6 ; 35.00 \%)$, effective ( $f=3 ; 20.00 \%)$ and hands-on ( $f=1 ; 6.66 \%)$ learning, supports out-of-class study opportunities $(f=1 ; 6.66 \%)$, individual learning $(f=2 ; 13.3 \%)$, and continuous repetition of words with various activities $(\mathrm{f}=1 ; 6.66 \%)$ as well as increases in-class interaction via peer interaction $(\mathrm{f}=1 ; 6.66 \%)$.

Some exemplary statements of the PS-ELTs who shared positive opinions about the use of web-supported SL model in the vocabulary teaching process are as follows:

"I use it, of course, because I saw one-on-one positive effects in myself, and I think that if I have the necessary background and infrastructure, I should evaluate it" (P.T.13). "Yes, I use it. I am thinking of using it as students show more interest in materials using technology." (P.T.3). 
Six PS-ELTs emphasized that they could use the web-supported SL model conditionally in vocabulary teaching processes. P.T.5 emphasized that she could use the model because it provides hands-on experience and permanent learning, but that students should volunteer and form a group with the people they want in her statement, "I use it. Because they learn by hands-on experiencing, which ensures permanence learning. However, I attach great importance to students volunteering and being a group with friends they want. Otherwise, I do not think it has any benefits. On the contrary, it gives harm. We broke down with our friends. There were many arguments in many groups." Another pre-service English language teacher (P.T.2) stressed that he can use the web-supported SL model not as a group work but as an individual study and that the duration of the activities should be kept long in his statement "I use it, but I use it as a personal study, not as group work. I do not think there will be a problem when the time for the activities is extended.". Pre-service English language teacher (P.T.28) suggested that the web-supported SL model would not be effective in younger age groups and could be used in some age groups by the words "I can use it in some age groups. But I do not think it can be an effective way for younger age groups.". P.T.9 indicated that she could use the web-supported SL model if there is a technological infrastructure by stating that "I use it if the necessary technological conditions and materials are available. I think it is much more effective by hands-on learning, experiencing, and using in life.". P.T.26, on the other hand, stated that he would not use the web-supported SL model and that the technology pushed the students to laziness, and this model was not suitable for children by indicating that "I use rarely. Because I want the child to feel and touch the material, to do something, to carry his trail, so I do not intend to use it much in the future. Furthermore, the conditions of our country are not suitable for this; unfortunately, there is a generation that has been pushed into laziness, and I think that if I use technology in the lesson, I will support this laziness more".

\subsection{Findings Related to the Fifth Sub-problem}

PS-ELTs stated that preparing vocabulary teaching materials according to the web-supported SL model contributed to their professional development. As seen in Figure 10, PS-ELTs underlined the fact that preparing their vocabulary teaching materials according to web-supported SL model helped to improve such skills as firstly conducting research $(f=3)$, finding solutions to the problems they face $(f=1)$, synthesizing $(f=1)$ and critical thinking $(\mathrm{f}=1)$. Some exemplary statements of PS-ELTs who state that the application helped to develop these skills are as follows:

“... we experienced how we could find solutions to situations that could challenge us when we became a teacher. Also, in my next working life, it helps me to learn the ways of doing research. We learned to use various sources and to synthesize these different sources." (P.T. 22). "...helps to Improve SL and vocabulary knowledge. Creative and critical thinking" (P.T.27).

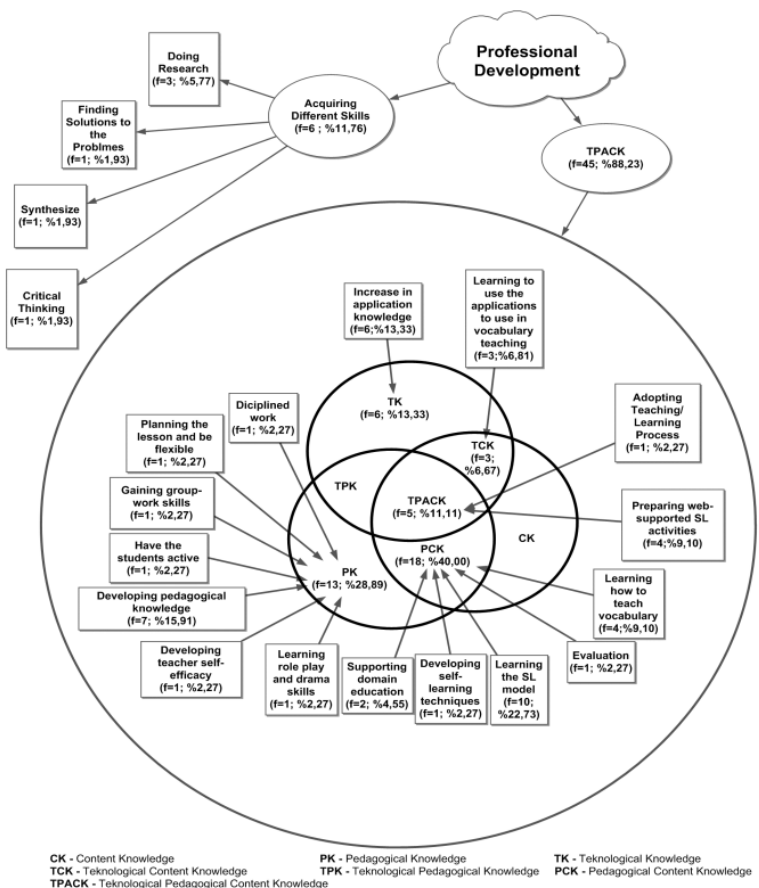

Figure 10. PS-ELTs' views on professional development $(\mathrm{n}=28)$ 
PS-ELTs expressed their opinions (Figure 10) on the development of technological pedagogical content knowledge ( $\mathrm{f}=45 ; 88.23 \%$ ) and its components: their technological knowledge (TK) $(\mathrm{f}=6,13.64 \%$ ), technological content knowledge (TCK) $(\mathrm{f}=3 ; 6.67 \%)$, pedagogical knowledge (PK) ( $\mathrm{f}=13 ; 28.89 \%$ ), pedagogical content knowledge (PCK) $(18 \% ; 40.00 \%)$ and technological pedagogical content knowledge (TPACK) $(\mathrm{f}=5 ; 11.11 \%)$. They also underlined that, in the process of preparing word learning materials using the web-supported SL model, they have improved their pedagogical knowledge ( $\mathrm{f}=7 ; 15.91 \%)$ and their teaching self-efficacy $(\mathrm{f}=1 ; 2.27 \%)$, learned role-play and drama techniques $(\mathrm{f}=1 ; 2.27 \%)$, how to activate the student ( $\mathrm{f}=1 ; 2.27 \%$ ), how to plan the course and how to be flexible during the application of the plan ( $\mathrm{f}=1$; $2.27 \%)$, and gained work discipline $(\mathrm{f}=1 ; 2.27 \%)$ and group work $(\mathrm{f}=1 ; 2.27 \%)$ skills. The development of PS-ELTs' content knowledge (vocabulary) is mentioned in vocabulary learning and teaching process.

Considering the views on pedagogical content knowledge, PS-ELTs highlighted that they learned how to use the SL model $(f=10 ; 22.73 \%)$, teach vocabulary $(f=4 ; 9.10 \%)$, and carry out the evaluation $(f=1 ; 2.27 \%)$. They also stated that the SL model contributed to their field education $(\mathrm{f}=2 ; 4,55 \%)$ and the development of personal learning techniques $(\mathrm{f}=1 ; 2.27 \%$ ). Since computers and web environments were used to prepare the materials in this study, PS-ELTs stated that their knowledge of the programs (stand-alone computer programs and web 2.0 apps) to create web-supported materials increased ( $\mathrm{f}=6 ; 13.33 \%$ ) as they searched for various programs to create their materials in the application process. Besides, regarding the technological content knowledge, they noted that they learned how to use the appropriate programs in the process of teaching vocabulary ( $\mathrm{f}=3 ; 6.81 \%$ ).

PS-ELTs stated that since they employed their technological knowledge, pedagogical knowledge and content knowledge in the application of the web-supported SL model, they learned how to prepare web-supported SL activities $(\mathrm{f}=4 ; 9.10 \%)$ and adapt the web-supported SL model to the vocabulary learning/teaching process ( $\mathrm{f}=$ $1 ; 2.27 \%)$. They also expressed that the process helped improve their technological pedagogical content knowledge. Some exemplary statements of PS-ELTs who express their opinions regarding professional development, that is, technological pedagogical content knowledge, are as follows:

"With this module, we once again practiced preparing lessons and exercises, which improved us. It was a study we prepared in harmony on time" (T.P.6). "It allowed me to discover websites where I can find many images and videos. I think it is a very successful study in terms of permanence of learning because we do many activities and evaluations about a word" (P.T.1).

\section{Discussion and Conclusion}

\subsection{Discussion on the Vocabulary Learning Process}

The first aim of the research was to have PS-ELTs to learn the words they did not know by preparing vocabulary materials according to the web-supported SL model in a web-supported SL environment. In foreign language education, vocabulary learning has been a significant problem for both learners and teachers. In the vocabulary learning/teaching process, the teacher gives a list of words and their equivalence in the mother tongue, while the students try to learn the meaning of these words in a context-free way. However, such a process does not go beyond trying to memorize the mother tongue equivalents of the words given in the target language (Shrum \& Glisan, 2015), and permanent learning cannot occur. The language learning process is similar to the process of construction in that just as the building can never be completed if there are no bricks to form the walls of the building, so are the words to develop language proficiency in the language learning process. Therefore, if learners go through an effective vocabulary learning process, learning the target language will also be comfortable and practical.

Whether PS-ELTs learned the target words during the application process and the learning was permanent or not were also viewed in this study. Academic achievement pre-test and post-test scores of the PS-ELTs in the control group were significantly different in favor of the post-test and close to the scores of the treatment group. It can be attributed to the expository teaching model, which is a teaching method that provides meaningful and permanent learning for students when fully implemented rather than presenting the subject deductively and supporting rote-learning. The reason why vocabulary learning processes are useful in the control group is thought to be due to the model used because the expository teaching model provides meaningful and active learning. After all, it runs cognitive processes (Ausubel, 2000). In his study, Clark (1992) found that the expository teaching model was moderately useful in answering knowledge questions and remembering information as a result of education. However, the difference between retention test scores of both groups indicates that the target vocabulary is remembered more by the PS-ELTs in the treatment group after an eight-week break. It means that the method used in the treatment group provides permanent learning. Besides, despite this difference in the retention test scores, PS-ELTs got lower scores from the vocabulary achievement 
retention test than those form the post-test. It may be because the application was considered to be a requirement of the class, as a result of which they put aside what they did the minute the application was over, and they were preparing for the Public Personnel Selection Exam (KPSS).

Similarly, it was found that the PS-ELTs in the treatment group got significantly higher scores from the post-test of the vocabulary achievement test, and this may be mostly due to the application. When the retention test of the vocabulary achievement test was administered to see if the application provided permanent learning, there was a significant difference between the post-test and retention test scores of both groups, and this difference was in favor of the post-test. That is, the average of the retention test scores that PS-ELTs obtained was lower than that from the post-test. However, when the pre-test and retention test scores were compared, it was observed that the retention test scores were high, and the difference was significant. This result may show that the application is useful in vocabulary learning processes. The learning process that takes place by providing different environments in which target content is employed provides the most effective way of learning by connecting both the classroom and the real environments outside the classroom (Sung, Chang \& Yang, 2015). PS-ELTs in the treatment group also used real sections from life to prepare web-supported SL materials. This finding also matches up with the results of the studies which examine the success of learners using the SL environments (Xiao-Fang \& Ting, 2011; Efe et al., 2011; Wicha \& Temdee, 2013; Chang \& Liu, 2013; Chou, 2015; Bilgin Uz, 2016).

PS-ELTs stated that the process of preparing vocabulary materials according to the web-supported SL model in the web-supported SL environment has a significant impact on their vocabulary learning process. The process provided permanent, comfortable, and active learning, and helped to increase their vocabulary knowledge. Also, using real-life situations and visuals for the words, studying and repeating them regularly during the creation of the materials, and the materials' appealing to the senses and supporting self-study supported their active learning. Gibbons (2009) and Snow (2010) reported that presenting the target content in situations causes permanent learning in the learner. Moreover, Wicha and Temdee (2013) and Yang (2011) emphasized that the participation of the learner in the practices is essential and that the learner actualizes active and permanent learning by hands-on experience. Contrary to these findings, Göktaş (2003) found that there was a significant difference between the achievement scores in the interim application tests in his experimental study; however, there was no significant difference between the post-test, transfer-test and follow-up test achievement scores of the groups. Although the web-supported SL model had a significant influence on their vocabulary learning processes, PS-ELTs shed light on the fact that there were problems due to the content of the study, group dynamics, and personal characteristics, as a result of which the results of the vocabulary achievement test were low. Zheng (2010) stated in his study that SL environments positively affect the achievement of the learners, but individual characteristics affect it. Furthermore, PS-ELTs attributed the reasons why they got low scores from the vocabulary achievement test to the fact that they confused the target words because they were too many and had close and metaphoric meanings. Another reason for not being able to score high in the achievement test may be due to the high discrimination index of the test items in the vocabulary achievement test.

\subsection{Discussion on the Vocabulary Teaching Process}

Situated learning is a learning method where learners construct meaning from real activities in their daily life where learning takes place (Stein, 1998). Moreover, SL is useful in the development of mental skills such as problem-solving, interpretation, understanding, transfer of knowledge, creativity as well as learning new information as a result of the ongoing interaction between learners and their environment (Clancey, 1995). It is also underlined that it is crucial to organize and present contexts based on a problem or situation for active learning in the classroom (Jonassen, 1991). Brown et al. (1989) suggest that teaching or learning vocabulary out of context is a slow and unsuccessful process, and vocabulary is mostly learned in real contexts. Besides, children can learn the language at an incredible speed when they actively participate in the environment in which the target language is spoken (Miller \& Gildea, 1987). Therefore, the second aim of this research is to enable PS-ELTs to prepare vocabulary materials according to the web-supported SL model in which they can effectively teach their students vocabulary, rather than giving their students a list of words and their meaning in the mother tongue. In the first sub-problem of the study, whether there is a significant difference (both intra-group and inter-group) between the SEB-SLEs of PS-ELTs in preparing web-supported SL environments and of those preparing expository teaching-learning environments was investigated. Also, their thoughts about their professional development were evaluated in line with the data obtained from the focus group interview, the open-ended interview form, student diaries, and online interview records.

The PS-ELTs' SEB-SLE scale pre-test and post-test results show that there is virtually the same increase in the SEB-SLE of the PS-ELTs in both groups. Although there is no study based on the SL model in the control group, 
the reasons for the prevalence of self-efficacy beliefs among the PS-ELTs in the control group may be because they talked about the applications with those in the treatment group and they were informed about the SL model in previous semesters. However, when the long-term retention test results of the SEB-SLE scale were examined, it was seen that the situation was different. While SEB-SLE retention test results of the treatment group increased positively as much as the score difference between the pre-test and post-test results of the treatment group, the control group's SEB-SLE retention test result decreased to the score they received in the pre-test. By this result, it can be said that there was a significant positive development in the SEB-SLEs of PS-ELTs in the treatment group. Nevertheless, the reason why there was a decrease in the scores of the control group may be because they discussed the practices with those in the treatment group and may have been negatively affected, which coincides with the findings of the studies (Göktaş, 2003; Lee et al., 2005; Dönmez, 2005; Ünlü, 2009; Yang et al., 2013) related to the effects of SL environment on the attitudes and self-efficacy perceptions of pre-service teachers.

The reason why the level of PS-ELTs' SEB-SLE is high is supported by the fact that the majority of PS-ELTs stated that they would use the web-supported SL model in their vocabulary teaching processes. PS-ELTs emphasized that they will use the model in their vocabulary teaching processes because the model provides abundant activities for the teaching process, supports motivation via drawing attention, is a student-oriented practice and applicable to different age groups, brings real situations to the classroom (vitality) and supports the effective use of technology. Ruso (2007), Huang et al. (2011), and Chang and Liu (2013) in their studies indicated that the practices performed in SL environments increase the motivation of the learners, which overlaps with the findings in this study. Contrary to the vast majority, only six PS-ELTs stated that they could use the SL model if they had the necessary technological infrastructure and performed the activities individually instead of group work, or else they did not intend to use it. These findings coincide with the findings of the studies by Şensoy (2013) and Bozu (2014). Şensoy (2013), in his study on teachers' using SL environments, determined that teachers frequently utilize SL environments in their classes, yet could not apply some activities due to technical deficiencies. Moreover, Bozu (2014) found in his study that teachers could not use SL environments in their lessons due to technical deficiencies.

The second sub-problem aims to reveal the power of PS-ELTs' TPACK-SC and SEB-SLE to predict their academic success in vocabulary learning. Results of the regression analysis showed that so that PS-ELTs can increase the level of their SEB-SLE. In other words, create a web-supported SL environment, they should have both content knowledge and TPACK. Technology is used to bring SL environments to the classroom (McLellan, 1994), and SL supports the development of technology-enhanced decision-making skills and instructional design (Angeli and Valanides, 2009). Furthermore, according to the SL perspective, for learners to transfer information, how and where information is learned is of great importance rather than what is learned (Greeno, Collins and Resnick, 1996). Effective practices or classroom activities are at the heart of TPACK. Therefore, PS-ELTs need to see how theoretical knowledge is transformed into practice and gain experience to create technology-supported activities (Niess, 2017). In other words, for PS-ELTs to use SL environments effectively in the classroom, their technological knowledge must also be substantial.

\subsection{Discussion on Professional Development Process}

Teachers need to know which technologies, which programs, and which content and how to teach so that they can bring the SL environment to the classroom. So, teachers need to use their TPACK effectively. Another aim of this study was to help PS-ELTs raise awareness about how to use the technology in the vocabulary learning-teaching process during the preparation of web-supported SL materials.

The pre-test and post-test results of the TPACK-SC applied to the PS-ELTs in both groups suggest that the preparation of the vocabulary learning material of both groups caused a significant increase in their TPACK-SC. As a result of the long-term retention-test applied eight weeks after the experimentation, no change was observed in the scores of their TPACK-SC and remained the same. The reason for this may be the fact that pre-service teachers find the opportunity to apply their theoretical knowledge in the process of preparing materials. Similarly, Phillips (2014) stated in his doctoral study that SL environments have a positive effect on the development of pre-service teachers' TPACK.

PS-ELTs stated that preparing vocabulary learning materials in the web-supported SL model contributed to their professional development. They also underlined that they gained the ability to conduct research, to produce solutions to the problems, to synthesize, and critical thinking while preparing web-supported situated vocabulary learning materials. Besides, they emphasized that during the process, their technological knowledge, technological content knowledge, pedagogical content knowledge, pedagogical knowledge, and technological 
pedagogical content knowledge apart from their technological pedagogical knowledge and content knowledge have developed. Additionally, considering the sub-dimensions of the TPACK-SC scale, it was seen that the average scores of the technological knowledge and technological pedagogical knowledge were at the highest level.

These results match up with the work by Lehiste (2015). In his study, Lehiste (2015) underlined that pre-service teachers showed an increase in all areas of their TPACK and that while there was an increase in technological knowledge and technological pedagogical content knowledge, there is a shallow development in content knowledge and pedagogical knowledge. In this study, while there was no finding related to the content knowledge, PS-ELTs stated that their pedagogical knowledge had improved. Moreover, Kurt, Akyel, Koçoğlu, and Mishra (2014) stated in their study with PS-ELTs that there was an improvement in pedagogical, technological, and content knowledge, and they used them actively.

\section{Conclusion}

In this study, the results obtained from the treatment group using the web-supported SL model and the control group using expository teaching model in the vocabulary learning and teaching process are given below:

- It was found that there was a significant difference between the achievement (post-test - pre-test) and retention test scores of the PS-ELTs in both the treatment and control groups in terms of their academic achievement in vocabulary learning and SEB-SLE. However, although a significant difference was observed between gain (post-test - pre-test) scores of the PS-ELTs in both the treatment and control groups in terms of TPACK-SC, no significant difference was between post and retention test scores.

- The results also showed that no significant difference was observed between the groups in terms of academic achievement and TPACK-SC of PS-ELTs. Nonetheless, a significant difference was in favor of the treatment group in terms of SEB-SLE.

- It is concluded that the better the PS-ELTs' technological pedagogical content knowledge and vocabulary knowledge (content knowledge), the easier it is to create web-supported SL environments.

- PS-ELTs emphasized that their preparation of vocabulary materials via the web-supported SL model had a significant effect ( $\mathrm{f}=117 ; 90 \%$ ) on their vocabulary learning. Besides, PS-ELTs stated that the application process provides permanent learning and helps increase vocabulary knowledge.

- Twenty-one pre-service teachers (75\%) stated that they consider the web-supported SL model as a useful and functional application and that they intend to use the model in vocabulary teaching processes since the model supports abundant activities and permanent learning.

- PS-ELTs also stressed that the process of preparing vocabulary learning material according to the web-supported SL model helped them to gain such skills as critical thinking, synthesizing, conducting research, and producing solutions. Besides, it also helped to improve their pedagogical knowledge, pedagogical content knowledge, technological knowledge, technological content knowledge, technological pedagogical content knowledge.

As a result, it was aimed to develop a model for PS-ELTs to be able to not only learn vocabulary themselves but also teach vocabulary to their students throughout their teaching life. As a result of the eight-week application, both the web-supported SL model applied in the treatment group and the expository teaching model applied in the control group were found to be useful models, which can be used in the process of vocabulary learning and teaching. Both applications are practical in terms of academic achievement and TPACK-SC. Besides, it was seen that PS-ELTs preparing vocabulary materials according to the web-supported SL model showed an increase in their vocabulary knowledge and learned how they could teach words and how they could combine technology, content knowledge, and learning-teaching process in the classroom. In other words, they learned how to use theory and practice together. Also, it was concluded that web-supported SL environments increased the PS-ELTs' self-efficacy beliefs.

\subsection{Suggestions and Recommendations}

Many factors, such as the level and characteristics of the target words, the learner's characteristics, the internal dynamics of the group, and the infrastructure should be taken into consideration when designing and developing web-supported SL environments to support the vocabulary learning process. Therefore, practitioners to create web-supported SL environments are proposed to consider the following suggestions: 


\subsubsection{Recommendations for Implementation}

- Theoretical courses can be designed according to the web-supported SL model so that theory and practice can be combined.

- PS-ELTs' preparing activities close to real situations was seen to be useful in the development of TPACK. Therefore, PS-ELTs should be encouraged to prepare web-supported SL environments in their theoretical courses and bring theory and practice together.

- That PS-ELTs prepare vocabulary teaching activities via web-supported SL model during their micro-teaching applications can be useful in terms of both improving their vocabulary and learning how to use the model.

- This study was conducted with 4th-grade PS-ELTs. Therefore, to examine the effectiveness of the web-supported SL environments on vocabulary learning, advanced words were selected intentionally. By using vocabulary in lower language levels (e.g., beginner, pre-intermediate), PS-ELTs may be able to prepare web-supported SL environments easily.

- Web-supported SL environments can be used not only in vocabulary learning/teaching processes but also in teaching other language skills.

\subsubsection{Suggestions for Researchers}

- This study was conducted with 4th-grade PS-ELTs. It was seen that they could not use the application effectively because of the anxiety for the Public Personnel Selection Exam (KPSS). Therefore, it is possible to compare the results to be obtained by repeating the same application in 1st, 2nd, and 3rd-year classes in ELT departments.

- Some classes where students conduct micro-teaching or prepare materials can be designed according to the web-supported SL model, and the development of TPACK of PS-ELTs can be evaluated.

- There were no significant differences between the web-supported SL model and the expository teaching model. Studies comparing different teaching models with the web-supported SL model can be conducted.

- Practical courses can be designed according to the web-supported SL model, and its effects can be examined.

\section{References}

Angeli, C., \& Valanides, N. (2009). Epistemological and methodological issues for the conceptualization, development, and assessment of ICT-TPCK: Advances in technological pedagogical content knowledge (TPCK). Computers and Education, 52(1), 154-168. https://doi.org/10.1016/j.compedu.2008.07.006

Ataizi, M. (1999). Bilgisayar destekli durumlu ögrrenmede bilişsel biçim ve içeriğin gerçeklik düzeyinin sorun çözme becerilerinin gelişimine etkisi. Unpublished Ph.D. Thesis. Anadolu Üniversitesi, Sosyal Bilimler Enstitüsü, Eskişehir. Retrieved from https://tez.yok.gov.tr/UlusalTezMerkezi/.

Ausubel, D.P. (2000). The acquisition and retention of knowledge: a cognitive view. Kluwer Academic Publishers. ISBN 9780792365051. https://doi.org/10.1007/978-94-015-9454-7

Bilgin Uz, Ç. (2016). Facilitating English as a foreign language learners' vocabulary learning, task completion, and contextual vocabulary exploration processes in a mobile supported situated learning environment. Unpublished Ph.D. Thesis. The Graduate School Of Natural and Applied Sciences. Middle East Technical University. Retrieved from https://tez.yok.gov.tr/UlusalTezMerkezi/.

Bozu, E. (2014). Öğrenme-öğretme ortamlarında durumlu öğrenme yaklaşımının uygulanması ve değerlendirilmesi. Unpublished MA Thesis. Fırat Üniversitesi Eğitim Bilimleri Enstitüsü. Elazığ. Retrieved from https://tez.yok.gov.tr/UlusalTezMerkezi/.

Brinck, I. (2007). Situated cognition, dynamic systems, and art: on artistic creativity and aesthetic experience. Janus Head, 9(2), 407-431.

Brown, J. S., Collinns, A., \& Duguid, P. (1989). Situated cognition and the culture of learning. Educational Researcher, 18(1), 32-42. https://doi.org/10.3102/0013189X018001032

Büyüköztürk, Ş. (2006). Sosyal bilimler için veri analizi el kitabı: istatistik, araştırma deseni, spss uygulamaları ve yorum (6. Baskı). Pegem A Yayıncılık. Ankara.

Can, T. (2004). Yabancı dil olarak ingilizce öğretmenlerinin yetiştirilmesinde kuram ve uygulama boyutuyla oluşturmacı yaklaşım. Unpublished MA Thesis. Sosyal Bilimler Enstitüsü İngiliz Dili Eğitimi Bölümü, İstanbul Üniversitesi. Retrieved from https://tez.yok.gov.tr/UlusalTezMerkezi/ 
Chang, Y.H., \& Liu, J. (2013). Applying an AR technique to enhance situated heritage learning in a ubiquitous learnıng environment. TOJET: The Turkish Online Journal of Educational Technology, 12(3), 21-32.

Chen, C. M., \& Li, Y. L. (2010). Personalized context-aware ubiquitous learning system for supporting effective English vocabulary learning. Interactive Learning Environments, 18(4), 341-364. https://doi.org/10.1080/10494820802602329

Chou, I-C. (2015). Situated learning: learn to tell English stories. Journal of Education and Training Studies, 2(4) ISSN 2324-805X E-ISSN 2324-8068. https://doi.org/10.11114/jets.v2i4.500

Chun, D., M., \& Plass, J. L. (1996). Effects of multimedia annotations on vocabulary acquisition. The Modern Language Journal, 80, 183-198. https://doi.org/10.1111/j.1540-4781.1996.tb01159.x

Clancey, W.J. (1995) A tutorial on situated learning: proceedings of the international conference on computers and education (Taiwan) Slf, J. (Eds.) Charlottesville, VA: AACE. 49-70.

Clark, J. H. (1992). The effects of expository teaching methodologies on student achievement of suburban students at the secondary level. Unpublished Ph.D. Thesis. The University of Illinois at Urbana-Champaign. Retrieved from https://www.ideals.illinois.edu/handle/2142/19021.

Collins, A., Hawkins, J., \& Carver, S. M. (1991). A cognitive apprenticeship for disadvantaged students. In B. Means, C. Chelemer and M. S. Knapp (Eds.) Teaching advanced skills to at-risk students. (s. 216-243). San Francisco: Jossey Bass.

Cresswell, J.W. (2015). A concise introduction to mixed methods research. SAGE Publications, Inc.

Dönmez, O. (2005). Üniversite düzeyinde durumlu karma öğrenme ortamının geliştirilmesi, gerçekleştirilmesi ve etkinliğinin incelenmesi. Unpublished MA Thesis. Hacettepe Üniversitesi, Fen Bilimleri Enstitüsü, Ankara. Retrieved from https://tez.yok.gov.tr/UlusalTezMerkezi/.

Efe, H., Demiröz, H., \& Akdemir, A.S. (2011). A situated learning practice for language teaching classes: teaching spoken English with authentic sketches. Sino-US English Teaching, 8(9), 549-555. ISSN 1539-8072.

Field, A. (2009). Discovering statistics using SPSS. 3rd ed. SAGE Publications Ltd.

Gibbons, G. (2009). Tornadoes: vocabulary self-collection strategy. New York: Holiday House.

Göktaş, İ. (2003). Bilgisayar ve sınıf ortamına dayalı durumlu öğrenmenin öğrenci başarısı ve tutumlarına etkisi. Unpublished Ph.D. Thesis. Ankara Üniversitesi, Eğitim Bilimleri Enstitüsü, Ankara. Retrieved from https://tez.yok.gov.tr/UlusalTezMerkezi/

Graham, R.C., Burgoyne, N., Cantrell, P., Smith, L., St. Clair L., \& Harris, R. (2009). Measuring the TPACK $\begin{array}{lllll}\text { confidence of in-service science teachers. TechTrends, } & \text { 53, }\end{array}$ https://doi.org/10.1007/s11528-009-0328-0

Greeno, J.G., Collins, A., \& Resnick, L.B. (1996). Cognition and Learning. D.C. Berliner ve R.C. Calfee (Ed.) Handbook of Educational Psychology. (s. 15-46). New York: McMillan. https://doi.org/10.1037/0278-7393.22.3.687

Haladyna, T. M. (1997). Writing test items to evaluate higher-order thinking. Boston, MA Allyn and Bacon.

Huang, C. S., Yang, S. J., Chiang, T. H., \& Su, A. Y. (2016). Effects of situated mobile learning approach on learning motivation and performance of EFL students. Journal of Educational Technology \& Society, 19(1), 263-276.

Huang, K., Lubin, I. A., \& Ge, X. (2011). Situated learning in an educational technology course for pre-service teachers. Teaching and Teacher Education, 27(8), 1200-1212. https://doi.org/10.1016/j.tate.2011.06.006

Huang, S., \& Eslami, Z. (2013). The use of dictionary and contextual guessing strategies for vocabulary learning by advanced English-language learners. English Language and Literature Studies, 3(3), 1. https://doi.org/10.5539/ells.v3n3p1

Huffman, S. (2011). The role of collaboration in developing 12 vocabulary knowledge through computer-assisted language quests. BC, Canada: CALICO: Mediated Learning Communities May 17-21 - University of Victoria. https://doi.org/10.31274/etd-180810-1190

Hwang, W. Y., Chen, H. S., Shadiev, R., Huang, R. Y. M., \& Chen, C. Y. (2014). Improving English as a foreign language writing in elementary schools using mobile devices in familiar situational contexts. Computer Assisted Language Learning, 27(5), 359-378. https://doi.org/10.1080/09588221.2012.733711 
Jaeyoung, J., \& Graf, S. (2008). An approach for personalized web-based vocabulary learning through word association games. SAINT '08 Proceedings of the 2008 International Symposium on Applications and the Internet. https://doi.org/10.1109/SAINT.2008.63

Jonassen, D. (1991). Objectivism vs. Constructivism. Educational Technology Research and Development, 39(3). https://doi.org/10.1007/BF02296434

Kessler, G., \& Bikowski, D. (2010). Developing collaborative autonomous learning abilities in computer-mediated language learning: Attention to meaning among students in wiki space. Computer Assisted Language Learning, 23(1), 41-58. https://doi.org/10.1080/09588220903467335

Kim, Y. S., \& Merriam S. B. (2010). Situated learning and identity development in Korean older adults' computer classroom. Adult Education Quarterly, 11(August)(60), 438. https://doi.org/10.1177/0741713610363019

Kirshner, D., \& Whitson, J.A. (1997). Situated Cognition: Social, Semiotic, and Psychological Perspectives. Mahwah, NJ: Lawrence Erlbaum Associates.

Kurt, G., Akyel, A., Koçoğlu, Z., \& Mishra, P. (2014). TPACK in practice: A qualitative study on technology integrated lesson planning and implementation of Turkish pre-service teachers of English. ELT Research Journal, 3(3).

Lave, J., \& Wenger, E. (1991). Situated learning: legitimate peripheral participation. Cambridge: Cambridge University Press. https://doi.org/10.1017/CBO9780511815355

Lee, S. H., Kim, J. W., Lee, J. H., \& Liu, X. (2005). The effectiveness of online situated environments for language learning. In the 21st Annual Conference on Distance Teaching and Learning. Retrieved from https://www.uwex.edu/disted/conference on 07.25.2015

Lehiste, P. (2015). The impact of a professional development program on in-service teachers' TPACK: a study from Estonia. Problems of Education in the 21st Century, 66, 18-28.

Liaw, M. L., \& Susan, B. L. M. (2010). Understanding telecollaboration through an analysis of intercultural $\begin{array}{llll}\text { discourse. } \quad \text { Computer } \quad \text { Assisted } & \text { Language }\end{array}$ https://doi.org/10.1080/09588220903467301

McLellan, H. (1994). Situated learning: continuing the conversation. Educational Technology, 34(10), 7-8.

Miles, M.M., \& Huberman, A.M. (1994). Qualitative data analysis: an expanded sourcebook. (2nd Ed.) Calif: SAGE Publications.

Miller, G.A., \& Gildea, P.M. (1987). How children learn words. Scientific American, 257, 94-99. https://doi.org/10.1038/scientificamerican0987-94

Mills, N. (2011). Situated learning through social networking communities: The development of joint enterprise, mutual engagement, and a shared repertoire. CALICO Journal, 28(2), 345-358 https://doi.org/10.11139/cj.28.2.345-368

Niess, M.L. (2017). Technological pedagogical content knowledge (TPACK) framework for K-12: teacher preparation emerging research and opportunities. USA: IGIGlobal. https://doi.org/10.4018/978-1-5225-1621-7

Özerbaş, D. H. S. (2004). Durumlu öğrenmenin duygusal zeka yeterliliklerinin geliştirilmesine etkisi. Unpublished Ph.D. Thesis. Ankara Üniversitesi, Eğitim Bilimleri Enstitüsü, Ankara. Retrieved from https://tez.yok.gov.tr/UlusalTezMerkezi/

Özverir, I., \& Herrington, J. (2011, June). Authentic activities in language learning: bringing real-world relevance to classroom activities. In World Conference on Educational Multimedia, Hypermedia and Telecommunications, 1, 1423-1428.

Peterson, M. (2009). Learner interaction in synchronous CMC: a sociocultural perspective. Computer Assisted Language Learning, 24(4), 303-321. https://doi.org/10.1080/09588220903184690

Phillips, M.D. (2014). Teacher's TPACK enactment in a community of practice. Unpublished Ph.D. Thesis. Monash University, Faculty of Education. Retrieved from https://www.researchgate.net/266858223.pdf.

Richards, J. C. (1976). The role of vocabulary teaching. TESOL Quarterly, 10(1), 77. https://doi.org/10.2307/3585941

Ruso, N. (2007). The influence of task-based learning on EFL classrooms. EFL Journal, 18, 1-23. 
Sandberg, J., Maris, M., \& de Geus, K. (2011). Mobile English Learning: An evidence-based study with fifth graders. Computers \& Education, 57(1), 1334-1347. https://doi.org/10.1016/j.compedu.2011.01.015

Shahrokni, S. A. (2009). Second language incidental vocabulary learning: The effect of online textual, pictorial, and textual pictorial glosses. The Electronic Journal for English as a Second Language, 13(3), 1-17.

Shih, Y.C., \& Yang, M.-T. (2008). A collaborative virtual environment for situated language learning using VEC3D. Educational Technology \& Society, 11(1), 56-68.

Shrum, J., \& Glisan, E. (2015). Teacher's handbook, contextualized language instruction. Cengage Learning. https://doi.org/10.2307/3587569

Snow, C. (2010). Academic language and the challenge of reading for learning about science. Science, 328, 450. https://doi.org/10.1126/science.1182597

Stein, D. (1998). Situated learning in adult education. Eric no: ED418250.

Sung, Y. T., Chang, K. E., \& Yang, J. M. (2015). How effective are mobile devices for language learning? A meta-analysis. Educational Research Review, 16, 68-84. https://doi.org/10.1016/j.edurev.2015.09.001

Şensoy, F. (2013). Coğrafya Derslerinden Durumlu Öğrenme (Yerleşik Öğrenme) Modelinin Uygulanabilirliğine Yönelik Öğretmen Görüşleri. Unpublished MA Thesis, Gazi Üniversitesi Eğitim Bilimler Enstitüsü, Ankara. Retrieved from https://tez.yok.gov.tr/UlusalTezMerkezi/.

Timur, B., \& Taşar, M. F. (2011). The adaptation of the technological pedagogical content knowledge confidence survey into Turkish. Gaziantep Üniversitesi Sosyal Bilimler Dergisi, 10(2), 839-856. Retrieved from https://dergipark.org.tr/tr/pub/jss/issue/24242/257006

Tretiakov A., \& Kinshuk ve Tretiakov, T. (2003). Designing multimedia support for situated learning. IEEE, Computer Society, 32-36. https://doi.org/10.1109/ICALT.2003.1215021

Ünal, C., \& İnan, H. Z. (2010). Students' perceptions of a situated learning environment. Procedia-Social and Behavioral Sciences, 2(2), 2171-2175. https://doi.org/10.1016/j.sbspro.2010.03.301

Ünlü, İ. (2009). İlköğretim 6. Sinıf sosyal bilgiler dersinde bilgisayar destekli sinıf ortamında durumlu ögrenmenin ögrencilerin akademik başarısına, tutumuna ve ögrenmenin kalıcllı̆g etkisi. Unpublished MA Thesis. Firat Üniversitesi, Sosyal Bilimler Enstitüsü, Elazı̆g. Retrieved from https://tez.yok.gov.tr/UlusalTezMerkezi/.

Webb, S. (2008). The effects of context on incidental vocabulary learning. Reading in a Foreign Language, 20(2), 232.

Wicha, S., \& Temdee, P. (2013). A situated English vocabulary and conversation learning system (SEVCLS) for Thai rural residents. 13th International Symposium on Communications and Information Technologies (ISCIT). (s. 808-813). IEEE Xplore. https://doi.org/10.1109/ISCIT.2013.6645972

Xiao-fang, Z., \& Ting, Y. (2011). Establish an English learning community based on situation and dialogue. US-China Foreign Language, 9(2), 123-129.

Yang, C.-C., Tseng, S.-S., Liao, A. Y. H., \& Liang, T. (2013). Situated poetry learning using multimedia resource sharing approach. Educational Technology \& Society, 16(2), 282-295. Retrieved March 01, 2016, from www.jstor.org/stable/jeductechsoci.16.2.282.

Yang, Y. F. (2011). Engaging students in an online situated language learning environment. Computer Assisted Language Learning, 24(2), 181-198. https://doi.org/10.1080/09588221.2010.538700

Zheng, R. (2010). Effects of situated learning on students' knowledge acquisition: an individual differences perspective. J. Educational Computing Research, 43(4), 467-487. https://doi.org/10.2190/EC.43.4.c

\section{Copyrights}

Copyright for this article is retained by the author(s), with first publication rights granted to the journal.

This is an open-access article distributed under the terms and conditions of the Creative Commons Attribution license (http://creativecommons.org/licenses/by/4.0/). 